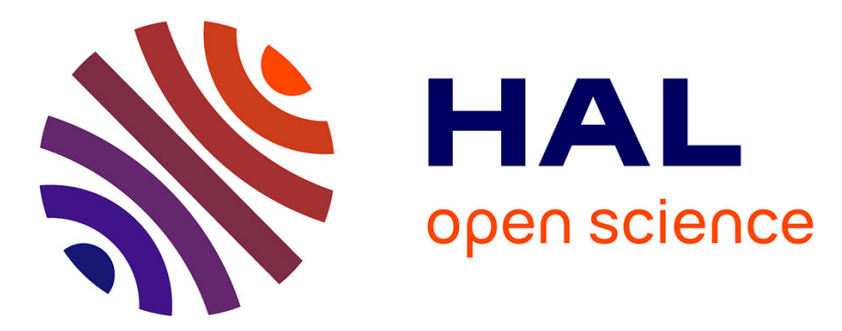

\title{
Petroleum Systems of Lebanon: an update and review
} R. Ghalayini, F. Nader, S. Bou Daher, N. Hawie, W. Chbat

\section{To cite this version:}

R. Ghalayini, F. Nader, S. Bou Daher, N. Hawie, W. Chbat. Petroleum Systems of Lebanon: an update and review. Journal of Petroleum Geology, 2018, 41 (2), pp.189-214. hal-01940792

\section{HAL Id: hal-01940792 \\ https: / hal-ifp.archives-ouvertes.fr/hal-01940792}

Submitted on 30 Nov 2018

HAL is a multi-disciplinary open access archive for the deposit and dissemination of scientific research documents, whether they are published or not. The documents may come from teaching and research institutions in France or abroad, or from public or private research centers.
L'archive ouverte pluridisciplinaire HAL, est destinée au dépôt et à la diffusion de documents scientifiques de niveau recherche, publiés ou non, émanant des établissements d'enseignement et de recherche français ou étrangers, des laboratoires publics ou privés. 
1 Title: Petroleum Systems of Lebanon

2 Authors: Ghalayini, R.(1), Nader, F.H. (2), Bou Daher, S. (3), Hawie, N. (4) \& Chbat,

3 W.E. (1)

4 Institutions:

5 (1)Lebanese Petroleum Administration, Georges Akouri Street, Beirut, Lebanon

6 (2) Geology Department, Geosciences Division IFP Energies Nouvelles, 1 \& 4 Av.

7 de Bois-Préau, 92852 Rueil-Malmaison, France.

8 (3) Department of Geosciences and Natural Resource Management, University of

9 Copenhagen, Øster Volgade 10, 1350 Copenhagen, Denmark.

10 (4) BeicipFranlab, 232 Av. de Bois-Préau, 92502 Rueil-Malmaison, France.

\section{Abstract}

12 Extensive 3D seismic data offshore Lebanon together with new investigations of

13 the onshore domain have resulted in a considerable wealth of information on the

14 regional geology and petroleum prospectivity. This article presents a new

15 interpretation of the Levant margin offshore Lebanon with an up-to-date review

16 of the geology of Lebanon and a new comprehensive insight on the petroleum

17 systems along the Eastern Mediterranean sector. The Lebanese onshore and

18 offshore territories are separated in this study into four different domains: the

19 deep basin, the Lattakia Ridge, the Levant margin and the onshore. Each of these

20 domains is marked by a general structural style and various stratigraphic

21 architectures, resulting in different source-reservoir-trap configurations. The

22 new subdivision impacts exploration as it highlights specific geographic areas

23 having distinct petroleum systems. This study takes into account all previously

24 published geological knowledge and provides new results from stratigraphic, 
25

26

27 licensing round.

\section{Introduction}

29 Lebanon, part of the larger Levant region, is located in the NW part of the

30 Arabian plate along its western active boundary with Africa (fig. 1). This area is

31 marked by the passage of the Levant Fracture System (LFS), the fold and thrust

32 belt of the Palmyrides ranges to the east and the stable foreland Levant basin to

33 the west. Lebanon and its offshore are considered as a promising petroleum

34 province as a result of more than $70 \mathrm{tcf}$ of proven natural gas reserves in nearby

35 countries, following the discovery of Tamar, Leviathan, Aphrodites and Zohr

36 between 2006 and 2015 (fig. 2). Onshore, recoverable reserves of Syria are

37 estimated at about 2.5 billion bbl of oil and about 8.5 TCF of gas, with productive

38 fields in the Palmyrides, the Euphrates graben and the Sinjar high (Barrier et al., 39 2014).

41 The latest petroleum activities in the Levant and the promising potential of

42 Lebanon have prompted the Lebanese government to acquire an extensive

43 amount of multiclient 3D seismic data to aid exploration offshore. Improved

44 knowledge of the geology of the Levant region was achieved by using this

45 unprecedented wealth of information and seismic data coverage and by

46 attracting considerable academic and industrial research projects, referenced

47 herein. A new model for the stratigraphic setting and filling of the basin has been

48 suggested based on seismic data and extensive fieldwork (Hawie et al., 2015). 
49 The structural framework of the Levant basin and margin has been described on

50 the light of new 3D reflection seismic data interpretation, and modelling

51 (Ghalayini et al., 2014; and references therein). A new geochemical assessment

52 of source rock potential based on extensive sampling onshore Lebanon has also

53 been completed (Bou Daher et al., 2014; Bou Daher et al., 2015). This has

54 resulted in the development of a new basin model for Lebanon and its offshore

55 based on an integration of all the newly acquired knowledge, providing an

56 updated picture of the hydrocarbon potential of Lebanon (Bou Daher et al.,

57 2016). In addition, a refined model for the crustal structure of the Levant Basin

58 was proposed (Inati et al., 2016), which directly impacts the petroleum systems

59 and the source rock maturity.

60

61 This article summarizes the results of the latest geological and petroleum

62 investigations in Lebanon and adds new up-to-date data - especially with regard

63 to potential petroleum systems. First, it presents new interpretation of the

64 Levant margin offshore Lebanon since the carbonate prospects have attracted

65 major attention following the Zohr discovery in carbonate reservoirs offshore

66 Egypt. Second, it subdivides the region into geological domains based on

67 multitude of stratigraphic, structural and geochemical data. Third, it discusses

68 the various petroleum aspects of each domain (potential source rocks,

69 reservoirs, and traps) and points out new objectives based on recent data and

70 neighboring discoveries. These results serve as a basis for the understanding of

71 the petroleum potential of Lebanon and provide a good case study on

72 exploration effectiveness and strategy at a critical time as the first offshore

73 licensing round has been set. 


\section{Exploration history}

75

76 Petroleum exploration in Lebanon started with the first legal decree issued in

771933 and amended in 1936. Twelve companies were actively involved in

78 exploration in Lebanon among which the 'Compagnie Libanaise des Pétroles'

79 (CLP) and the 'Syria Petroleum Company' (SPC) were the largest (Wetzel, 1974).

80 The SPC, which was a subsidiary of the Iraq Petroleum Company, drilled the first

81 well in Terbol in 1947 and failed to reach economic accumulations. It has since

82 relinquished all its concessions in Lebanon and concentrated its activity in Syria.

83 The CLP drilled five wells in the Bekaa between 1953 and 1964, four of which

84 with foreign partners, but without any commercial result. The CLP was the only

85 company to hold concessions amounting to $5200 \mathrm{Km}^{2}$. Exploration was not only

86 undertaken onshore, as Shaheen-Oxoco had offshore permits next to Tripoli. In

87 1970, the first seismic data was acquired by Oxoco offshore north Lebanon and

88 in 1971 Delta acquired $320 \mathrm{~km}$ of 2D seismic lines in addition to a gravity survey

89 on the Shaheen permit.

90

91 The acquisition of several regional 2D seismic reflection surveys by Spectrum

92 and TGS in 2000 and 2002 respectively, led to mapping of several promising

93 leads in the subsalt units. Between 2006 and 2012 PGS acquired $9700 \mathrm{Km}^{2}$ of

94 multiclient 3D seismic data followed by Spectrum who also acquired additional

$955172 \mathrm{~km}^{2}$ of multiclient 3D seismic data between 2012 and 2013 in the deep-

96 water offshore Lebanon resulting in an exceptional wealth of information for the

97 offshore basin. The new data has indicated a promising hydrocarbon potential 
98

99

\section{0}

101

102

103

104

105

106

107

108

109

110

112 Bordering the Levant Basin at its NW boundary is the Lattakia Ridge. This Late

113 Cretaceous structure was established as a result of the subduction of Africa

114 beneath Eurasia starting in the Maastrichtian (Frizon de Lamotte et al., 2011;

115 Stampfli and Hochard, 2009). Continuous compression has marked the region till

116 modern days with an accelerated rollback of the subduction zone along the

117 Hellenic-Cyprus arc during the Tortonian (Le Pichon and Kreamer, 2010) which

118 led to renewed fold-thrust activity in the middle-upper Miocene along the

119 Lattakia Ridge (Hall et al., 2005; Robertson et al., 1996). A regional geodynamic

120 event was witnessed in the Messinian and Pliocene causing a westward tectonic

121 escape of the Anatolian microplate with a component of anticlockwise rotation 
122 (Le Pichon and Kreamer, 2010; Sengor and Yilmaz, 1981). It has directly affected

123 the Lattakia Ridge which was reactivated into a sinistral strike-slip motion (Hall

124 et al., 2005). These geodynamic events were marked in both the Levant Basin

125 and onshore Lebanon by reactivation of structures, and a decrease in the lateral

126 motion of the LFS (Freund et al., 1970; Ghalayini et al., 2014; Le Pichon and

127 Gaulier, 1988; Quennell, 1984). It is also at this time, that the accelerated uplift of

128 the pre-existing Lebanese structures took place (Walley, 1998; Ghalayini et al., 129 2017; Beydoun, 1999).

130

131 The thickness of the crust gradually decreases westward from the Palmyrides to

132 the Levant Basin, with $44 \mathrm{~km}$ in the SW Palmyrides, $35 \mathrm{~km}$ beneath the anti-

133 Lebanon ranges and $27 \mathrm{~km}$ beneath Mount Lebanon (Brew et al., 2001; Khair et

134 al., 1993). This westward thinning of the crust beneath Syria and Lebanon

135 indicates a transition between a crust of continental type east of the Levant

136 margin, transitioning to a thinned continental crust of 8-10 km thickness

137 beneath the Levant Basin as evidenced by modern gravity inversion (Inati et al.,

138 2016) and refraction seismic profiles (Ben-Avraham et al., 2002; Makris et al.,

139 1983; Netzeband et al., 2006). This gradual, smooth thickness transition is the

140 result of the Permo-Jurassic rifting of Pangea, causing the break-off of

141 continental blocks from the Afro-Arabian plate to form the Neo-Tethys ocean

142 (Garfunkel, 1998; Robertson, 1998) and pointing to successive regimes of

143 extension that did not reach a real break up stage.

\section{Methods and data}


146 Interpretation of three seismic lines along the margin offshore north and south

147 Lebanon were performed (figs 3 to 6). The data used consist of pre-stack depth 148 migrated 3D seismic cube acquired in 2012 by PGS. Streamer length was $7050 \mathrm{~m}$ 149 long at a spacing of $12.5 \mathrm{~m}$ and $25 \mathrm{~m}$ shot point intervals. The interpretation was 150 performed on depth-converted sections. Because no well data were available,

151 time to depth conversion was done using a velocity model built from stacking 152 velocities.

153 Levant Margin north of Lebanon

$154 \quad$ Observations

155

15611 horizons were identified in seismic data based on impedance contrast

157 variations and following the interpretation of Hawie et al. (2014) (fig. 3). Horizon

158 RN1 separates non-continuous and low amplitude reflectors from the overlying

159 semi-continuous and relatively brighter package. The latter is exhibiting growth

160 strata and fanning geometries. RN2 is a continuous very bright reflector with a

161 strong impedance contrast. Toward the deep basin, it separates a set of bright

162 and stacked continuous reflectors package from non-continuous and dim

163 reflectors. RN3 marks the top of a series of three stacked reflectors package in

164 the east. To the west of the line, it forms an angular unconformity surface in

165 which the underlying unit is truncated. The overlying reflectors also exhibit

166 relatively lower amplitudes. RN4 exhibits a strong impedance contrast and

167 separate chaotic reflectors above from the stacked and bright reflectors below.

168 RN5 is a continuous horizon with a strong impedance contrast marking the top

169 of the low amplitude unit to the east from more continuous and bright reflectors 
170 above. It continues westward to the deep basin in which it is still marked by a

171 strong impedance contrast. Horizons RN6 to RN11 were picked up based on the

172 interpretation of Hawie et al. (2014).

173

174 The unit between RN2 and RN3 exhibits significant seismic facies variation

175 toward the deep basin in which continuous semi-bright reflectors appear to be

176 transitioning to chaotic reflectors in the middle. Further west, the unit is

177 dominated by a series of stacked and bright reflectors. Similar observations can

178 be made on the unit between RN3 and RN5 to the east in which the reflectors

179 become chaotic in the centre of the line and the overall unit adopts a wedge

180 shape geometry.

181

182

Interpretation

183

184 The fan-shaped geometry of reflectors between RN1 and RN2 point to the

185 presence of growth strata suggesting that normal faults are present at this depth.

186 The latter are NE trending parallel to the coastline and are dipping to the NW.

187 Similar extensional structures are documented in the southern Levant and

188 believed to have nucleated during the Triassic as a result of Tethyan rifting (e.g.

189 Gardosh et al. 2010). Therefore, units below RN1 are likely the pre-rift package

190 while units between RN1 and RN2 are the syn-rift package. This could be

191 attributed to the Permian and Triassic-Lower Jurassic units respectively. As RN2

192 is not displaced by faulting and separates deformed units below from non-

193 deformed units above, it could correspond to the break-up unconformity of mid-

194 Jurassic age (Hawie et al., 2014). RN2 therefore marks the initiation of tectonic 
195 quiescence and gentle subsidence of the Levant region starting the mid to late

196 Jurassic. The seismic package between RN2 and RN3 likely represents the

197 Jurassic unit composed of shallow-water, inner to middle shelf carbonates. Its

198 thickness of $1-1.5 \mathrm{~km}$ is in coherence with the thickness of the Jurassic in north

199 Lebanon (Nader et al., 2016; Dubertret, 1955) and is conformable with the

200 seismic facies interpretation of Hawie et al. (2014). Therefore, RN3 could refer to

201 the Late Jurassic-Early Cretaceous sequence boundary. The seismic facies

202 transition from continuous to chaotic reflectors indicate mass transport or talus

203 deposits originating from the Jurassic carbonate platform and deposited at the

204 distal end of the margin over a slope. The abrupt facies variation into high

205 amplitude bright reflectors toward the distal basin could point to the presence of

206 Jurassic clastic units away from the margin.

207

208 The unit between RN3 and RN4 exhibit a set of stacked high amplitude reflectors

209 indicating different facies than the adjacent carbonates. They are likely

210 representing thick bedding which alludes to sand packages of a possibly Lower

211 Cretaceous age. Therefore, this unit could be analogous to the onshore

212 Hauterivian Chouf formation, and RN4 could likely represent the top

213 Hauterivian. The overlying wedge-shape of the unit and the chaotic reflectors

214 associated could represent mass transport deposits or carbonate talus

215 originating from the Cretaceous carbonate succession along the margin and

216 onshore (Hawie et al., 2014). RN5 horizon corresponds to a major marine

217 onlapping surface and therefore could represent the Senonian unconformity

218 horizon (Hawie et al., 2014; Gardosh et al., 2011). On top of the Senonian

219 unconformity, the high amplitude package should be Tertiary in age as it overlies 
220 the Cretaceous unit. This unit displays high amplitude reflectors with similar

221 seismic facies to the underlying carbonates unit. Therefore, it could represent

222 Eocene to Miocene carbonate successions. The presence of such Tertiary

223 carbonate units along the Levant margin has been discussed by Hawie et al.

224 (2014).

225 Levant Margin south of Lebanon

$226 \quad$ Observations

227

228 The southern Levant margin offshore Lebanon is marked by a specific structural

229 element termed the Saida-Tyr plateau (STP) which is a $2500 \mathrm{~km}^{2}$ elevated

230 Mesozoic plateau as observed in the Senonian unconformity depth map (fig. 4). It

231 is differentiated from the deep Levant basin by large crustal faults to is north and

232 west (figs. 5-6) and is characterized by a thinner Cenozoic unit thickness relative

233 to the remainder of the basin (Hawie et al., 2014).

234

23513 horizons were identified in seismic data based on the interpretation of Hawie

236 et al. (2014) and through correlation with the Adloun well, located $5 \mathrm{~km}$ east of

237 the seismic line (fig. 5). It was drilled to a depth of $2150 \mathrm{~m}$ and reaches the Upper

238 Jurassic unit (Beydoun, 1977). Horizon RS1 separates chaotic non-continuous

239 horizons from a set of semi-continuous thick and bright horizons above. RS2

240 exhibits a strong impedance contrast separating the overlying chaotic and dim

241 horizons from bright and underlying semi-continuous horizons. It is challenging

242 to assess the continuity of RS1 and RS2 horizons to the west in the deep basin.

243 Horizons RS3 to RS8 are extrapolated from well data and consist of stacked high 
244 amplitude set of reflectors, with occasional dimming. Horizon RS8 marks the

245 boundary between stacked high amplitude bright reflectors to the east, and

246 stacked continuous medium to high amplitude reflectors to the west. The latter

247 package is pinching out and exhibits onlap on RS8. Horizons RS9 to RS13 are

248 picked up based on the interpretation of Hawie et al. (2014).

250 The seismic units between horizon RS2 and RS3, and horizons RS4 and RS5 are

251 thinning to the west and disappear. Their seismic facies change abruptly from

252 stacked bright horizons to chaotic. On top of horizon RS2, pinnacle shape

253 buildups are observed. They cover an area of about $200 \mathrm{Km}^{2}$.

254

255 Large vertical displacement related to vertical faults is observed north and west

256 of the plateau. The northern bounding fault displaces RS8 horizon $2 \mathrm{~km}$ upward

257 and locally forms a mini-basin along RS12 (fig. 5). The faults to the west have

258 positive-flower geometries with two anticlines observed along their strike (fig.

259 6). ENE-WSW to ESE-WNW normal faults are observed at the easternmost STP

260 (fig. 5) having a displacement of few hundred meters and extend between RS1

261 and RS8 horizons. Their strike is ENE-WSW to ESE-WSW.

262

263

Interpretation

264

265 From correlation with well data, horizons RS3 to RS7 correspond to Top Jurassic, 266 Top Hauterivian, Top Aptian, Top Albian and Top Cennomanian. As RS8 horizon

267 is truncating the Turonian and Senonian units as well as deeper units to the west,

268 it is believed to be the Senonian unconformity horizon (e.g. Hawie et al., 2013). 
269 The thickness between RS3 and RS2 is 1.5 to $2 \mathrm{Km}$, slightly higher than the total

270 expected thickness of the Jurassic unit south of Lebanon (Nader et al., 2016;

271 Dubertret, 1955). Horizon RS2 exhibits a strong impedance contrast, probably

272 indicating a transition between primarily dolomite succession to evaporites.

273 Therefore, RS2 is likely the top of the mid Triassic. The thickness between RS2

274 and RS1 is 1 to $1.5 \mathrm{~km}$ in accordance with the expected thickness of the Triassic

275 in Lebanon (Nader et al., 2016; Beydoun and Habib, 1995) and therefore RS1 is

276 likely the base Triassic. This interpretation points to an extension of the broad

277 geometries observed onshore to the Levant margin offshore with possible lateral

278 facies changes expected away from the coast.

279

280 The interpretation of the Tertiary units is adopted from Hawie et al. (2014) in

281 which horizons RS9 to RS13 correspond to the Eocene Unconformity, Base

282 Miocene, Base mid Miocene, Base Messinian and Base Pliocene respectively.

283 These units are overlying the Mesozoic units found eastward and are onlapping

284 on the Senonian Unconformity horizon, while to east and closer to the shoreline,

285 the Mesozoic is directly overlain by the Pliocene and the Messinian unit is not

286 observed in seismic data. This likely indicates an existing topographic high prior

287 to the deposition of the Tertiary unit. The westward seismic facies variation

288 observed in the Jurassic and Cretaceous units could be interpreted as talus

289 deposits originating from the carbonate platform in the East. Overlying the RS2

290 horizon, the pinnacle shape geometries could consist of local build-ups or

291 isolated carbonate mounds, though it is challenging to assess their true nature

292 from seismic data alone. 
294 The large vertical displacement observed on the ENE trending northern

295 bounding fault, referred to as the Saida fault, is likely related to an old Mesozoic

296 extensional regime. Ghalayini et al. (2014) argues that this fault is reactivated

297 into a dextral strike-slip in the Late Miocene due to the en-echelon anticlines

298 observed in the upper Miocene unit. Onshore, the Saida fault is correlated with

299 the passage of the Damour fault zone, which consists of a deformation zone of

300 multiple ENE-WSW faults, separating Mount-Lebanon into two different

301 compartments. It has been suggested that both the Saida and the Damour faults

302 are the westward continuation of the Jhar fault in Syria due to the similar trend,

303 evolution history and crustal configuration north and south of these faults

304 (Ghalayini et al., 2017). Therefore, it is likely that the STP also marks a crustal

305 transition and could be underlain by a continental crust (e.g. Ghalayini et al.,

306 2014). The western bounding faults displace vertically the Mesozoic unit for

307 more than $2 \mathrm{~km}$, also suggesting an older extensional episode prior to the

308 Cenozoic. The positive flower structures and the folding in the Tertiary units

309 might indicate a transpressive regime starting in the Late Miocene times. The

310 ENE-WSW to ESE-WNW normal faults documented at the easternmost STP (fig.

311 5) are similar to faults well documented in southern Mount Lebanon (Homberg

312 et al., 2009; Homberg et al., 2010). It is very likely that these faults belong to the

313 same fault family as the ones documented onshore and therefore were active

314 during the Cretaceous times (e.g. Homberg et al. 2009)

\section{Main geological domains}


317 Based on the available geological data and on the new interpretation of the

318 margin, the Lebanese onshore/offshore area is differentiated into four geological

319 domains, having distinct sedimentological and structural features: (1) the distal,

320 deeper basin, (2) The Lattakia Ridge, (3) the Levant Margin and (3) the onshore

321 (fig. 7). The following sub-sections describe the main geological features of these

322 domains and are as such a review of the available literature. The lithostragraphic

323 column of the Levant region summarizes the stratigraphy, structures and

324 expected petroleum systems (fig. 8).

325

326 The Deep Basin

328 It has formed on an attenuated crust (Inati et al., 2016) during the Triassic and

329 Jurassic when the Neo-Tethys has opened up following the rifting of Pangea. It is

330 characterised by a thick Cenozoic sedimentary cover reaching over $8 \mathrm{~km}$

331 thickness, overlying a Mesozoic succession (Gardosh and Druckman, 2006;

332 Hawie et al., 2013; Roberts and Peace, 2007). The main structural features

333 prevalent in this domain are the normal faults and the NE trending anticlines.

334

Stratigraphic setting

336

337 Nine horizons were identified in the Levant basin offshore Lebanon in seismic

338 data and correlated with nearby wells (Hawie et al., 2013). They are believed to

339 correspond to the Mid Jurassic, Jurassic-Cretaceous boundary, Senonian

340 unconformity, Eocene unconformity, Base Miocene, Base mid Miocene, Base 
341 Messinian and Base Pliocene. The seismic packages are defined by their large-

342 scale reflection configurations, impedance contrasts, specific stratigraphic

343 contacts with their lower and upper bounding surfaces, stratal terminations and

344 overall seismic facies. As the pre-Tertiary units in the deep basin were not drilled

345 elsewhere in the Levant basin, it is very challenging to separate and seismically

346 characterize the Mesozoic strata in this domain. The Cenozoic units, such as the

347 Eocene, Oligocene-Miocene, Messinian and Pliocene, possess higher certainty

348 and are laterally continuous throughout the Levant basin.

350 A mixed carbonate-siliciclastic system characterizes the stratigraphy of the deep

351 basin. The documented units consist of Mesozoic rocks, possibly deep-water

352 carbonates or clastics, below the Senonian unconformity. The overlying Cenozoic

353 consists of several units starting with the undercompacted shales of Paleogene

354 age (Montadert et al., 2014). The Oligo-Miocene units consist of siliciclastic

355 materials deposited as a result of marginal uplift and sea-level lowstands during

356 the late Eocene and Oligocene (Haq and Al-qahtani, 2005) which have led to

357 erosion on the margin and clastic deposition in the basin (Gardosh et al., 2008).

358 Hawie et al. (2013) documented the presence of canyons incising the margin

359 within the middle-upper Miocene offshore northern Lebanon, together with

360 various characteristics of deep-water sedimentary environments such as

361 channels, levees and sheeted turbidite lobes towards the distal basin.

362

363 The thick Oligo-Miocene succession in the Levant Basin can be explained by

364 considerable sedimentary flux originating from a proto Nile (Steinberg et al.,

365 2011) in which distal turbidites and basin floor fans could extend as far as the 
366

367

368

369 (Hawie et al., 2015). Therefore, it is most likely that the filling was also

370

371

372

373

374

375

376

377

378

379

380

381

382

383

384

385

offshore Lebanon (Dolson et al., 2005; Hawie et al., 2013). However, it was

shown that a multi-source system better describes the filling of the basin based

on forward stratigraphic modelling constrained by seismic, well and field data

accomplished by erosion from the eastern margin together with provenance of

sediments from the north, mainly from the Lattakia region in Syria. Overlying the

Oligo-Miocene, the Messinian unit is a $\sim 1.7 \mathrm{~km}$ thick evaporitic sequence

deposited as a result of the sequestration of the Mediterranean Sea at the end of

the Miocene and contains mass transport complexes at the base, clastic materials

intercalations and halite (Gorini et al., 2015). A return to a pelagic/hemi-pelagic

sedimentation is attested during the Pliocene with the deposition of deep-water

turbidites in the basin (Hawie et al., 2013).

Structural setting

$\mathrm{NE}$ trending anticlines are documented in the deep basin and are 5 to $15 \mathrm{~km}$ long structures deforming the Oligo-Miocene units only and detaching in the Eocene unit (fig. 9). Ghalayini et al. (2014) argues that these anticlines were folded immediately prior to, or at the onset of the Messinian salinity crisis due to absence of growth strata in the pre-Messinian units, and erosion of the anticlinal crest along the base Messinian horizon. They were formed due to regional geodynamics caused by the collision and suturing of Arabia with Eurasia. In the southern Levant, similar trending anticlines were formed and are overlying deep-seated Mesozoic extensional structures (Gardosh and Druckman, 2006). It is not clear if the anticlines offshore Lebanon are overlying deeper reactivated 
391 structures, but thickness variations below the ones found closer to the margin 392 strongly suggest so (Ghalayini et al., 2014).

393

394 The normal faults are layer bound, found ubiquitously in the Oligo-Miocene units 395 in the deep basin. The faults are regularly spaced with a dip of $60^{\circ}$ either to the 396 NE or SW. At depth, all the faults consistently die out at the same intra-Eocene 397 detachment level (fig. 10), which has been interpreted to have a regionally 398 developed shale sequence acting as the basal detachment surface for these faults 399 (Montadert et al., 2014; Hawie et al., 2013; Kosi et al., 2012). As there is no NE400 SW extension documented in the basin during the Oligo-Miocene, an exclusive 401 tectonic origin for their formation or a nucleation model in relation to the 402 Messinian Salinity Crisis (MSC) has been refuted (Ghalayini et al., 2016). Detailed 403 analysis of the fault growth and evolution have showed that they have nucleated 404 during the Early Miocene and remained syn-sedimentary till the Late Miocene 405 (Ghalayini et al., 2016). A likely nucleation mechanism for these faults could be 406 related to diagenetic reactions in the Oligo-Miocene units leading to volumetric 407 contraction of the host rock and causing intra-formational normal faulting (e.g. 408 Cartwright 2011, Davies et al. 2009, Wrona et al. 2015).

409 The Lattakia Ridge

411 The Lattakia Ridge is a prominent structure that is found at the NW part of the 412 Levant basin offshore Lebanon. It is part of the Cyprus Arc system and stretches 413 from the Syrian region in the NE to offshore southern Cyprus. It is characterized 414 by a strong topographic high observed at the seafloor. 
418 The stratigraphy in this domain is similar to the rest of the Levant basin, albeit

419 with different thicknesses of units, especially to the west of the ridge itself. The

420 same horizons in the deep basin are also documented along the Lattakia Ridge.

421 The Late Cretaceous convergence has resulted in a depocenter in the lower

422 Tertiary in this region evidenced by thicker Eocene and Oligocene units south

423 and south-east of the Lattakia Ridge (Hawie et al., 2013). The Miocene unit,

424 however, is thinning considerably and reaches up to $1 \mathrm{~km}$ in total thickness. It is

425 suggested that the proximity to a northern sedimentary source, i.e. from Syria,

426 could result in coarser sediment and more clastic material in the Oligo-Miocene

427 unit of this domain, possibly pointing to better reservoir qualities (Hawie et al., 428 2015).

Structural setting

433 The Latakia Ridge consists of a series of south-east verging thrusts forming

434 prominent NE trending narrow structures and having a profound bathymetric

435 expression (fig. 11). Several anticlines are found adjacent to the Lattakia ridge.

436 These are symmetrical NE-trending structures, which in the Oligo-Miocene units

437 appear very similar to compressional anticlines, while in the deeper Eocene and

438 Mesozoic unit they consist of deep-seated SE verging thrusts with steep SE limbs

439 (fig. 11). Back thrusts are documented along this ridge and are believed to have 
440 been initiated during the Pliocene as a result of transpression (Hall et al., 2005;

441 Symeou et al., in review). This complex structural style of the Lattakia Ridge is a 442 result of the geodynamic setting of the Eastern Mediterranean region discussed 443 above.

444 The Levant margin

446 The Levant margin domain covers the area adjacent to the Lebanese shoreline 447 and comprises the Saida-Tyr plateau, a small narrow strip in front of Beirut, and 448 a larger platform north of Lebanon (fig. 7). It is differentiated from the Cenozoic 449 deeper basin by its thick Mesozoic carbonate succession on top of which the 450 Cenozoic units are pinching out and onlapping. It is generally acknowledged that 451 the Levant margin encompasses the onshore domain in Lebanon, including

452 Mount Lebanon (Nader 2011). However, for the purpose of this paper, we 453 differentiate the Levant margin from the inner onshore domain (i.e. Mount 454 Lebanon and the Bekaa Valley) as the depositional setting and associated 455 petroleum systems are expected to be different (Hawie et al., 2014; Bou Daher et 456 al., 2016; Bou Daher et al., 2015; Nader, 2014).

457 Stratigraphic setting

460 Interpretation of the stratigraphy along the Levant margin is provided by Hawie 461 et al. (2013), in which they correlate the units identified in seismic data to those 462 documented onshore (Dubertret, 1955; Hawie et al., 2014; Nader, 2011). An 
463 updated interpretation of the expected stratigraphy of Levant margin is provided

464 in the previous section of this manuscript.

465

466

Structural setting

467

468 The structures of the southern Levant margin were described in the previous

469 section. They show an analogy with those described by Ghalayini et al. (2014) on

470 the strike-slip faults, and those of Homberg et al. (2009) regarding the normal

471 faults in southern Lebanon. From south to north, the structural setting of the

472 Levant margin offshore Lebanon is markedly different. At the latitude of Beirut, a

473 narrow strip is documented in which the Mesozoic carbonate platform is

474 considerably narrow or absent. It is correlated with very steeply dipping

475 Cretaceous strata onshore adjacent to this location (Dubertret, 1955), in contrast

476 with the broad plateau documented along the southern margin (Homberg et al.,

477 2010; Hancock and Atiya, 1979). In the north, the Tertiary units gently onlap the

478 Mesozoic succession and the overall margin is cross-cut by E-W trending dextral

479 strike-slip faults. En-echelon anticlines, oriented NE-SW, are documented in the

480 Upper Miocene unit along the strike of these strike-slip faults. Several NNE

481 trending Mesozoic normal faults are documented in the Permo-Triassic units and

482 could be related to the Mesozoic rifting event (Hawie et al., 2013).

483 The onshore domain

484

485 The onshore domain comprises the prominent Lebanese ranges including Mount

486 Lebanon, Anti-Lebanon and the Bekaa Valley in between (fig. 1). It is located at 
487 the margins of the Levant and the Palmyra Basins, which have similar ages and 488 tectonic histories (Ghalayini et al., 2017; Nader, 2014). Therefore, it has been 489 stated that the Lebanese ranges are part of the Palmyra Basin due to the large 490 resemblance between the structural features, the similar crustal configuration 491 and the analogous stratigraphic intervals (Ghalayini et al., 2017; Beydoun and 492 Habib, 1995; Nader, 2014), yet the Lebanese ranges have been further affected 493 by the passage of the LFS in the Late Miocene and Pliocene. The main folding 494 phase of the Palmyrides and the initial uplift of Mount Lebanon, took place 495 during the Late Oligocene or Early Miocene (Brew et al., 2001; Sawaf et al., 2001; 496 Chaimov et al., 1992; Beydoun, 1999; Hawie et al., 2014; Ghalayini et al., 2017). 497 Stratigraphic setting

500 The documented units observed in outcrops range from the mid-Jurassic to the 501 Upper Cretaceous in Mount Lebanon, with Paleogene and Neogene sediments 502 closer to the shoreline and in the Bekaa valley. Pre-Jurassic units are not exposed 503 onshore. Nevertheless, correlation with the geology of the Syrian Palmyra basin 504 allowed suggesting that the Triassic sequence is expected to extend westward 505 and is thicker in Lebanon (Beydoun and Habib, 1995). This is based on extensive 506 deep exploration wells and seismic data in Syria (Sawaf et al., 2001; Chaimov et 507 al., 1993; Brew et al., 2001) as well as an old electro-resistivity survey that 508 indicated the presence of a conductive unit located at $650 \mathrm{~m}$ below the oldest 509 outcropping Jurassic outcrop (Renouard, 1955) which was attributed to a 510 potential Triassic evaporate layer (Beydoun, 1977; Beydoun and Habib, 1995). 511 Therefore, it is likely that the Triassic in Lebanon is analogous to Syria, which has 
512 also been proposed based on interpretation of reflection seismic data onshore

513 northern Lebanon (Nader et al., 2016). The Triassic unit in the Palmyrides is

514 documented to consist of a Lower Triassic Amanus shale formation and a middle

515 to Upper Triassic Kurrachine formation. The latter is subdivided into two units, a

516 dolomite and an overlying anhydrite sequence. Equivalent units are identified in

517 Jordan (Luning and Kuss, 2014) and in the southern Levant margin (Gardosh and

518 Tannenbaum, 2014).

519

520 The Jurassic sequence in Lebanon is approximately $1,700 \mathrm{~m}$ thick, and could

521 reach 2,700 m thick in the Mount Hermon region of the southern Anti-Lebanon

522 ranges (Dubertret, 1955). The Lower Jurassic consists of a dark and thick

523 dolomite sequence termed the Chouane Dolomites. It is overlain by the mid to

524 late Jurassic Kesrouane Limestone Formation deposited during a period of post-

525 rift subsidence in shallow water environment. Above the Kesrouane formation,

526 lies the Kimmeridgian Bhannes volcanic unit which consists of a mixture of

527 carbonates, marls, lavas and pyroclastics. It is distinctive in some location by its

528 red soils and hard basalts, with occasional pillow lavas. The thickness of this unit

529 decreases southward and is in average around $80-100 \mathrm{~m}$ thick. Overlying the

530 Bhannes volcanics, is a 60-80 m thick cliff-forming formation termed the Bikfaya

531 formation. It consists of massive bedded limestone deposited in a period of sea

532 level rise. The end of the Jurassic is marked by a return to shallow water

533 sedimentation with deposition of ferruginous oolitic limestone of the Salima

534 formation.

535 
536 The Cretaceous sedimentary cycle starts with deposition of the Hauterivian

537 Chouf sandstone formation (Maksoud et al., 2014; Walley, 1997). This unit is

538 between 5-300 m thick across Lebanon and thins northward reflecting possible

539 clastic provenance from the southeast. It consists of ferruginous brown to white

540 sandstone with clays, coaly shales and volcanics. It was deposited under a fluvial

541 to deltaic littoral environment. The overlying Barremian Abieh formation varies

542 between fossiliferous limestone, marls and sandstones and represents a

543 transition between the fluvial Chouf and the overlying shallow marine late

544 Barremian to Aptian units. The latter is a conspicuous cliff-forming formation

545 clearly visible throughout all of Lebanon, with a thickness of about $50 \mathrm{~m}$

546 (Maksoud et al., 2014). It consists of a single massive grey limestone. Small scale

547 rudist and stromatoporoidal reef buildups are visible in some locations. It

548 represents a sequence of shallow marine transgressive carbonate facies linked to

549 early Aptian eustatic rise. The overlying Albian corresponds to thin bedded

550 carbonates, marls and terrigenous sand. It represents a brief return to

551 terrigenous clastic deposition, in a general marine setting, before sea levels

552 caused renewed carbonate deposition.

553

554 The upper part of the Cretaceous and early Paleogene is almost entirely

555 composed of carbonate. The Cennomanian Sannine formation is $600 \mathrm{~m}$ thick and

556 consists of medium to thick bedded shallow water limestones and marly

557 limestone. This sequence thickens to the west with increasing thin bedded chalk

558 and cherty pelagic sediments along the coast. It is possible that these lateral

559 facies change and thickness increase could point to a shift from shallow water

560 deposition in the east, to deeper environments westward dominated by 
561 carbonate turbidite deposits (Hawie et al., 2014). The overlying Turonian unit is

$562 \quad 200-300 \mathrm{~m}$ thick and represents a continuation of the carbonate deposition of

563 the Cennomanian and is characterized by thin finely bedded, chalky micrites and

564 cherts with abundance of Hippurite fossils. The Senonian/Campanian-

565 Maastrichtian Chekka formation consists of very dark grey to white sequence of

566 chalks and marly limestone units. Its thickness ranges from 100 to $500 \mathrm{~m}$ with

567 the thickest succession documented in the southern Bekaa valley and is made of

568 chalk and marly limestone. It has a very good source rock potential as it contains

569 organic rich argillaceous limestone with TOC values between 2 and 10\% (Bou

570 Daher et al., 2014; Bou Daher et al., 2015).

571

572 The overlying Paleocene units are $300 \mathrm{~m}$ thick and consist of chalky limestones

573 and marls. Nummulitic middle Eocene limestone have been documented in the

574 Bekaa (Dubertret, 1955) where they reach up to $900 \mathrm{~m}$ in thickness (Hawie et al.,

575 2014) and in south of Lebanon. The upper Eocene and Oligocene units are absent

576 in all of Lebanon due to uplift and erosion of the margin during the Early

577 Miocene compressive folding event (Walley, 1998), except of one outcrop south

578 of Lebanon (Müller et al., 2010). The middle Miocene is outcropping and consists

579 of continental lacustrine facies in the Bekaa in contrast with the Miocene open

580 marine facies along the margin (Hawie et al., 2014; Dubertret, 1955). The

581 Pliocene in this area is referred to as the Zahle formation (Nader et al., 2016) and

582 corresponds to clastic deposits, breccias, silt, marl and lacustrine limestone,

583 overlain by alluvial fan conglomerates (Dubertret, 1955).

584 
586

587 Mount Lebanon is a NNE trending structure. It exhibits two different structural 588 styles, similar to the Palmyrides ranges (Brew et al., 2001), separated by a deep 589 crustal fault that forms the westward extension of the Jhar fault in the 590 Palmyrides (Ghalayini et al., 2017; Walley, 1998). Northern Mount Lebanon 591 consists of a broad and symmetric box-fold anticline, (Renouard, 1955; Beydoun 592 and Habib, 1995), while southern Mount Lebanon is topographically lower and 593 the deformation zone includes several shorter wavelength folds including a tight 594 SE verging overfold termed the Niha-Barouk anticline (Dubertret, 1955; Walley, 595 1998). Anti-Lebanon is an anticlinal structure very similar to Mount Lebanon 596 located more inland and merges topographically with the Syrian Palmyrides 597 ranges in the south. The Bekaa valley, which is dominated by a thick Tertiary to 598 recent continental succession, separates the two mountain ranges. The valley is 599 narrow in the south in the Hasbaya area and widens northward into the Homs 600 Plain in Syria.

602 The Yammouneh Fault passes through Mount Lebanon and forms a continuation 603 of the plate boundary between Arabia and Africa that stretches from Aqaba in 604 the south to Taurus in the North. In Lebanon, it reaches $160 \mathrm{~km}$ length and 605 bounds the eastern side of southern Mount Lebanon, while it cuts through its 606 northern counterpart. It is believed to be an ancient fault system from pre607 Cambrian times (Butler et al., 1998). The LFS effect in Lebanon is mostly 608 tranpsressive resulting in a restraining bend and causing large uplift of the 609 existing structures during the Pliocene. Since the late Quaternary, it is believed to 
610 accommodate principally strike-slip movements (Daëron et al., 2004; Gomez et

611 al., 2006). Transpression and strike-slip tectonics are mainly accommodated by

612 several faults including the Roum and Serghaya Faults. They are major sinistral

613 strike-slip faults branching from the southern LFS in the Golan Heights and

614 accommodate part of the displacement along the LFS (Gomez et al., 2001; Butler

615 et al., 1998).

616

617 Several ENE-WSW, currently active, dextral strike-slip faults are documented

618 along Mount Lebanon (Gedeon, 1999) and extend to the Levant margin offshore

619 (Ghalayini et al. 2014). These faults have most likely nucleated during the

620 Mesozoic as normal faults during the breakup of Pangaea and were subsequently

621 reactivated during the Neogene compression (Collin et al. 2010; Ghalayini et al.

622 2014). Similar faults are also found in the Palmyra basin further east.

623 Petroleum Systems

$624 \quad$ Source rocks and maturity

625

626 Potential source rocks are thought to exist in units between the Permian to

627 Pliocene based on regional stratigraphic correlation, field investigations and

628 geochemical analysis. The major potential source rocks are described here

629 below.

630

631

The deep basin and Lattakia Ridge

632 
633 Geochemical analysis of gas samples from Middle Jurassic to Pliocene reservoirs

634 along the southeastern margin of the Levant Basin proved the presence of five

635 thermogenic and biogenic sources (Feinstein et al., 2002). Offshore Lebanon, the

636 Permian and Triassic thermogenic sources - if present - are believed to generate

637 petroleum between 90 and 34 Ma in the deep basin (Bou Daher et al., 2016). The

638 Upper Jurassic Kimmeridgian thermogenic source rocks have most probably

639 generated oil between the Late Cretaceous and the Late Miocene. The Upper

640 Cretaceous Campanian might constitute good thermogenic source rocks which

641 have produced hydrocarbons between 34 and 16 Ma. However, it is expected

642 that in the deep basin, the Campanian source rock quality and TOC content

643 would decline (Bou Daher et al., 2015). Paleocene and Eocene thermogenic

644 source rocks have probably produced hydrocarbons during the Oligocene and

645 are still active in some parts of the basin.

646

647 The Oligocene unit might constitute potential thermogenic source rocks which

648 have started to generate hydrocarbons at around 6 Ma and are in the maturity

649 window at the present day. In addition, the Oligocene is believed to contain a

650 promising biogenic potential in the deep basin in which generation of biogenic

651 gas might have occurred between 18.5 and $6 \mathrm{Ma}$, while on the Lattakia Ridge and

652 in the more proximal basinal realm it might still be ongoing (Bou Daher et al.,

$6532016)$ as the units are thinner and located at shallower intervals. In fact, the most

654 productive biogenic source rocks in the southern Levant are thought to be within

655 the Oligocene sequence (Gardosh and Tannenbaum, 2014) and these are

656 expected to extend northward to Lebanon (Hawie et al., 2013; Nader, 2014).

657 Other biogenic source rocks include the lower and middle Miocene from which 
658 methane is believed to have been expelled during the Messinian and is currently

659 ongoing (Bou Daher et al., 2016). Based on thermal history modelling, Bou Daher

660 et al (2016) predicted that a thickness of 700 to $1500 \mathrm{~m}$ of sub-Messinian

661 Miocene succession is within the biogenic zone at present day. Detailed

662 information on source rock kinetics, maps of source rock maturation and

663 transformation ratios are presented in Bou Daher et al. (2016).

664

665

The Levant margin and onshore

666

667 Permian and Triassic source rocks - if present - would have generated

668 hydrocarbon between 75 Ma to present day along the margin and onshore (Bou

669 Daher et al., 2016). In Syria, the upper Permian/Lower Triassic Amanus

670 dolomites are very good source rocks for Triassic Reservoirs in the Palmyrides

671 (Barrier et al., 2014) and might therefore be as good in the Levant margin and

672 onshore. Similarly, the Upper Jurassic Kimmeridgian source rocks most probably

673 generated oil between the Oligocene to the present day along the margin (Bou

674 Daher et al., 2016) with minor amount on the onshore in the Late Miocene which

675 were most probably washed out by meteoric waters (Nader and Swennen,

676 2004a). However, in the deeply buried Jurassic under the Bekaa Valley, the

677 Kimmeridgian source rocks are in the oil window today.

678

679 The Campanian source rocks appears not to have been buried deep enough in

680 Mount Lebanon to generate hydrocarbon. In the Bekaa valley and along the

681 margin, however, the Campanian is in the maturity window and minor

682 generation might have occurred (Bou Daher et al., 2015). Geochemical data 
683 suggest that the these source rocks are rich in organic sulphur at high TOC (Bou 684 Daher et al., 2014; Bou Daher et al., 2015) leading to hydrocarbon generation at 685 earlier stages of thermal maturity (Bou Daher et al. 2016). Large amounts of 686 immature solid bitumen are found in caves and along fault planes in the Bekaa 687 which are typical for early stages of hydrocarbon generation from type IIS 688 kerogen (Bou Daher et al., 2015).

\section{Reservoirs}

690

691 The main reservoirs in the deep basin are found in the Oligo-Miocene unit and

692 consist of sand deposited in deep-water turbidite systems (Gardosh et al., 2008;

693 Hawie et al., 2013). In the lower Miocene unit, the Tamar sand is considered as

694 the best reservoir interval, consisting of sand with high net-to-gross and high

695 porosity/permeability in the range of $20-27 \%$ and $500-1000$ md respectively

696 (Gardosh and Tannenbaum, 2014). The fact that the Cenozoic unit in the deep

697 basin offshore Lebanon is much thicker than its southern counterpart may

698 suggest that the equivalent potential reservoirs might also be thicker.

699 Investigation of the normal fault system offshore Lebanon has revealed that the

700 growth of faults has been affected by mechanical stratigraphy caused by a strong

701 competent lower Miocene unit with faults nucleating in incompetent fine grained

702 sediments. The competent interval is interpreted to consist of a $\sim 100 \mathrm{~m}$ thick

703 sandy unit equivalent of the Tamar sand in the south (Ghalayini et al., 2016) or

704 could correspond to another lithology that is mechanically more resistant to

705 faulting.

706 
707 In the northernmost part of the deep basin and in the Lattakia Ridge domain,

708 seismic facies interpretation (Hawie et al., 2013) point that the main reservoirs

709 are possibly located in the upper Miocene and suggest an increased sand content

710 at the base Oligocene. The fact that the normal faults have smaller heights and

711 displacement in this area point that there is a barrier to vertical fault

712 propagation (Ghalayini et al., 2014). As the faults do not propagate to the upper

713 Miocene and lower Oligocene units, it is likely that the latter units consist of

714 incompetent lithologies which might be attributed to coarse clastics or sand. The

715 provenance of clastic material in this area is most likely from a northerly source,

716 probably from the Lattakia region in Syria. In addition, the erosion of Cretaceous

717 to Miocene carbonate platforms contemporaneously with Mount Lebanon's

718 accelerated uplift in the Late Miocene/Pliocene, could lead to more

719 conglomeratic material from the northern Lebanese ranges (Hawie et al., 2015;

720 Hawie et al., 2013).

721

722 Along the Levant margin, the Jurassic carbonate platform is far from meteoric

723 influence prevalent onshore (Nader and Swennen, 2004a). This fact, together

724 with the predicted presence of fracture-associated hydrothermal dolomites

725 could form effective reservoirs in the Jurassic carbonate platforms. The Lower

726 Cretaceous Chouf sandstones are correlated to the Rutbah formation in Syria,

727 which constitutes the principal reservoir in the Euphrates Graben (Barrier et al.,

728 2014; Sawaf et al., 2001), and to the Helez formation in the southern Levant,

729 which constitutes the reservoir for the Helez field (Shenhav, 1971). Therefore,

730 the Chouf sandstone might form good reservoirs in the margin offshore. Other

731 units in the Cretaceous, such as the Albian and the Aptian, could form good 
732 reservoirs consisting of isolated reefal buildups similar to the Eratoshtenes

733 margin (Hawie et al., 2013; Montadert et al., 2014; Esestime et al., 2016).

734 Younger reservoirs along the Levant margin consist of the lateral ends of the

735 Oligo-Miocene clastic units onlapping on the Mesozoic carbonate platforms.

736 These reservoirs are believed to be of good quality due to their proximity to the

737 Mount Lebanon sedimentary source than their deep basin's equivalent. Miocene

738 reefs are also documented on paleo-highs along the northern margin and could

739 provide good reservoirs (Hawie et al., 2013; Hawie et al., 2014).

740

741 In the onshore domain below Mount Lebanon, the expected reservoirs are pre-

742 Jurassic. All exposed units are subject to severe weathering and influx of

743 meteoric waters, strongly deteriorating the reservoir quality (Nader and

744 Swennen, 2004a). Good reservoirs could belong to the Permian to lower Triassic

745 Amanus sand formation consisting of shales interbedded with channel

746 sandstones and siltstone beds together with the lower to mid Triassic

747 Kurrachine unit consisting of dolomite and sandy intervals. These units are

748 important oil and gas reservoirs in the Palmyrides (Barrier et al., 2014) and in

749 the southern Levant's as they are equivalent to the Mihilla formation (Gardosh

750 and Tannenbaum, 2014). In the Bekaa region, the reservoirs are believed to be

751 Jurassic limestones protected from meteoric invasion, Lower Cretaceous

752 sandstone of the Chouf formation, Upper Cretaceous Senonian fractured

753 carbonates and Eocene nummulitic limestone.

$754 \quad$ Seal

755 
756 In the deep basin, the Paleocene/Eocene package is believed to form a strong

757 impermeable unit sealing the deeper reservoirs and preventing vertical

758 hydrocarbon migration from deeper intervals. The consistent detachment of

759 normal faults on the Eocene unconformity horizon (fig. 10) together with the

760 chaotic seismic facies and weak amplitudes observed in the Paleocene/Eocene

761 unit point that the latter is likely constituted by shales (Kosi et al., 2012) and

762 highly overpressured rocks (Montadert et al., 2014). In the Oligo-Miocene unit,

763 intra-formational shale or clay may constitute good seals for Miocene reservoirs

764 similar to the Tamar and other fields in the south (Gardosh et al., 2008). In this

765 unit, the normal faults could either form good lateral seals at present day or act

766 as conduits to hydrocarbon migration. In fact, the maximum documented

767 displacement on these faults is around $350 \mathrm{~m}$, causing a large offset of reservoir

768 against seal lithologies, increasing the likelihood of impermeability along fault

769 planes. In contrast, the same faults are observed to cross-cut the Tamar,

770 Aphrodite and Leviathan fields in the southern Levant basin but they do not

771 seem to affect the continuity of the reservoirs (Gardosh and Tannenbaum, 2014).

772 Therefore, this juxtaposition relationship still needs to be checked during

773 drilling. The shallowest cap rocks in the basin are the Messinian salts forming up

774 to $1500 \mathrm{~m}$ of evaporites and are as such considered to be an optimal seal if

775 underlying reservoirs are present.

777 The cap-rocks in the Lattakia Ridge are the same as the ones in the deep basin. In

778 this area, the complex deformation and extensive fracturation has most probably

779 affected the sealing potential of all units. This effect is most pronounced at the

780 Lattakia ridge itself and diminishes south-eastward toward the deep basin. In 
781 addition, the Messinian unit is absent on top of the ridge while thinning

782 considerably in the adjacent areas. Gas chimneys are frequently observed in the

783 area where the Messinian is absent and/or thinning on top of anticlines SE of the

784 Lattakia Ridge. In one particular example, gas accumulations in the shallow

785 upper Miocene reservoirs were possibly leaked out when the seal was thinning

786 and absent, as evidenced by the chimneys documented only in the absence of the

787 salt (fig. 12).

788

789 Along the Levant margin, potential cap rocks are the Lower Triassic evaporites of

790 the Kurrachine formation that are probably extending to the offshore carbonate

791 platform. The Kimmeridgian volcanic formation might also constitute a good seal

792 for deeper reservoirs, even though this unit is not laterally homogenous

793 (Dubertret, 1955) with expected facies change toward the basin. Cretaceous

794 clays, marls, and basalts could represent good cap rocks for the underlying

795 reservoirs. The Messinian unit in the Levant margin is either considerably

796 thinning in some locations (fig. 3) or is absent in others (fig. 5) which could

797 diminish the Messinian seal quality in this location.

798

799 Onshore, the expected thick Upper Triassic evaporites of the Kurrachine

800 Formation seal the underlying dolomitic reservoirs and protect them from

801 meteoric influence since the uplift of Mount Lebanon (Nader, 2011).They are

802 well documented to provide a regional seal in the Palmyrides (Barrier et al.,

803 2014; Sawaf et al., 2001) and in the southern Levant with the equivalent

804 Saharonim and Mihilla Formations (Gardosh and Tannenbaum, 2014). In the

805 Bekaa, intra-formational volcanic, marly and shaly units of Jurassic and 
806 Cretaceous age could seal the Jurassic and Cretaceous reservoirs. The Paleocene

807 calcareous shales might form a good seal as well as a protection to meteoric

808 infiltration in the Bekaa.

809

810

Traps and migration

811

812 Trap formation in the deep basin offshore Lebanon is mostly related to structural

813 processes in sub-salt units. The structural traps consist of (1) NE trending

814 anticlines in the Oligo-Miocene, detaching on the Eocene unconformity horizon

815 and folded immediately prior to, or at the onset of the Messinian salinity crisis;

816 (2) NE trending transpressive anticlines and positive flower structures found

817 primarily in the south west of the STP and formed during the Late Miocene and

818 (3) Oligo-Miocene tilted fault blocks that nucleated during the lower Miocene

819 and active during Miocene time. Migration of hydrocarbon from biogenic source

820 rocks may have been aided by the intense faulting and fracturing of the Oligo-

821 Miocene unit. As discussed earlier, the faults may constitute a good seal at

822 present day and provide 3-way closures. Their nucleation time during the early

823 Miocene and their continuous activity throughout the Miocene time (Ghalayini et

824 al., 2016) make these faults permeable throughout the Miocene. Therefore, any

825 petroleum migration after the Oligocene could result in charging the reservoirs

826 in the Oligo-Miocene unit.

827

828 In the Lattakia Ridge domain, the trap type is mostly structural with symmetrical

829 anticlines in the Cenozoic unit underlain by deep-seated SE verging thrust faults, 
830 providing excellent four-way closures. These anticlines are found surrounding

831 the Lattakia Ridge as of the Late Cretaceous time, but the ridge itself is a poor

832 trap due to the lack of closure as a result of intense uplift and erosion of the

833 Cenozoic units. Migration of hydrocarbons from source to reservoirs must have

834 happened through the numerous faults and fractures associated with the intense

835 deformation of the Lattakia ridge since the Late Cretaceous times. Deformation

836 continued till modern day indicating that several faults are still active and

837 implying that they could form effective migration pathways.

838

839 Along the Levant Margin, trap mechanism is mostly stratigraphic within the

840 Mesozoic carbonate platform. Other stratigraphic traps include pinchout of the

841 Early Cretaceous sand sealed by Cretaceous carbonates in addition to pinchout of

842 Oligo-Miocene sandy units onto shallower Mesozoic strata and sealed by intra-

843 Miocene shale. Structural traps include inversion structures, such as reactivated

844 ENE-WSW strike-slip faults (e.g. Ghalayini et al. 2014) forming 4-way dip

845 closures below the Messinian. Along the margin, pre-existing and inverted faults

846 may have played an important role in hydrocarbon migration from the deep

847 Mesozoic source rocks to shallower reservoirs. As these faults were active

848 throughout much of the geological time, they might have been permeable during

849 the Mesozoic and Cenozoic times.

850

851 Onshore, the traps are mostly of structural type, consisting of 4-way dip closure

852 anticlines formed by the transpression along the LFS (Nader, 2014; Nader et al.,

853 2016). Potential large traps are the Qartaba anticline (Nader, 2014; Nader, 2011)

854 together with other large structures, such as the Sir-Ed-Denie, Barouk-Niha and 
855 Jezzine, which might form a good trap geometry in the subsurface similar to the

856 Qartaba anticline, and could be potential prospects (Beydoun and Habib, 1995;

857 Beydoun, 1977). They might have formed in the Late Miocene in association with

858 the activity of the LFS. In the Bekaa valley, potential traps might be structures

859 located beneath the quaternary cover (e.g. Nader et al., 2016).

860 Overall Discussion

861

862 Based on 3D seismic data, a new interpretation of the Levant margin offshore

863 Lebanon is proposed. In the southern margin, the seismic horizons were tied to

864 nearby well which resulted in updated stratigraphic subdivisions of the Saida-

865 Tyr plateau. The Triassic unit is likely present based on the predicted unit

866 thicknesses in Lebanon (Beydoun and Habib, 1995). This is conformable with the

867 finding of Nader et al. (2016) onshore in which they suggest the presence of high

868 amplitude seismic horizons which they interpret as the Top Triassic based on

869 regional thicknesses. The high impedance contrasts along this horizon in the

870 southern margin could be related to the presence of evaporites within the

871 Triassic but this still needs to be checked by drilling.

872

873 Recently, the discovery of Zohr in carbonate reservoirs around the Eratosthenes

874 seamount has opened new play concepts in the basin and attracted attention to

875 the carbonate potential (e.g. Esestime et al., 2016; Montadert et al., 2014). The

876 presented interpretation along the margin refines our understanding of the

877 expected carbonate sequences which could open up new play concepts. The

878 Mesozoic carbonates are considered to have good porosity from correlation with 
879

880

881

882

883

884

885

886

887

888

889

890

891 This new interpretation of the margin reduces risk in exploration as it provides

892 new elements for the petroleum system and hence new potential prospects. The

893 Lower Cretaceous sandstone is identified in the northern margin,

894 stratigraphically trapped between the Jurassic and Cretaceous carbonate talus.

895 This unit offshore appears to be thicker than its equivalent onshore (e.g.

896 Dubertret, 1955; Bellos, 2008). This could be related to an established

897 basin/margin differentiation since at least the Early Cretaceous in which a larger

898 accommodation space is available for the Nubian sand to be deposited offshore.

899 Hawie et al. (2013) indeed argues for a general westward facies variation in

900 Mesozoic sequences caused by a transition to deeper basinal environments.

901

902 The relatively good reservoir properties of the Lower Cretaceous sandstone unit

903 onshore Lebanon and Syria (e.g. Bellos, 2008) and the hydrocarbon production 
904 from this same unit in the southern Levant (Shenhav, 1971; Gardosh and

905 Tannenbaum, 2014), suggest that similar prospective plays might well exist

906 offshore Lebanon. In fact, DHI's such as bright spots and a potential flat-spot is

907 observed in seismic data (fig. 13) which invoke hydrocarbon accumulations,

908 originating from thermogenic source rocks. This unit extends along the entire

909 margin offshore Lebanon and therefore could be associated to large prospects.

910 The challenge, however, is the depth of this play being around $8 \mathrm{~km}$ in some

911 locations, resulting in potentially high pressure reservoirs.

912

913 Additional DHI's, such as flat spots, can also be observed within the Oligocene

914 unit along the Levant margin (fig. 14). With the relatively better reservoir quality

915 expected in this location (Hawie et al., 2015), it is very likely that Oligo-Miocene

916 pinchout prospects could also be promising. As the flat spot is located below the

917 Base Miocene horizon, this indicates that the seal might be around the Base

918 Miocene. This could point that towards the margin, the base Miocene is probably

919 be associated with shaly/marly or fine grained facies and transitions to coarser

920 grains or sandy facies toward the basin.

\section{Significance of geological domains}

922

923 This contribution aims at updating the general knowledge on the potential

924 petroleum systems of Lebanon ahead to the first Lebanese offshore licensing

925 round. Based on a comprehensive review of previously published and achieved

926 integrated research work (geodynamics, stratigraphy, structural geology and

927 geochemistry) together with the interpretation of two key seismic profiles, we 
928 provide here an original subdivision of the Lebanon onshore/offshore into four

$\$ 29$ distinct geological domains.

930

931 This subdivision is more adequate when assessing the petroleum potential of

932 Lebanon as every domain is characterized by a variable petroleum system. This

933 is due to different geological characteristics of each domain resulting in different

934 source-reservoir-trap configurations, and hence different petroleum plays.

935 Therefore, this subdivision becomes very beneficial during exploration as it

936 focuses attention to specific plays which are a unique to each domain.

937

938 Previous studies have grouped the Lattakia Ridge and the deep basin into one

939 domain termed the 'offshore' in which a similar petroleum system is expected

940 (Nader and Swennen, 2004b). More detailed analysis, however, suggests

941 otherwise. The source rocks charging the reservoirs in the Lattakia Ridge are

942 supposed to be both thermogenic and biogenic, while in the deep basin the

943 biogenic ones are dominant (Bou Daher et al., 2016). In addition, the traps are of

944 Late Cretaceous age and the reservoirs intervals are unlikely to consist of the

945 Tamar sands but could belong to other intervals (Ghalayini et al., 2014; Ghalayini

946 et al., 2016; Hawie et al., 2015). Such geological variations necessitate to

947 associate the Lattakia Ridge to an independent domain of the deep basin.

948

949 The onshore domain have been discussed abundantly and the expected

950 petroleum system is well described from regional correlations and field studies

951 (e.g. Beydoun, 1977; Beydoun and Habib, 1995; Nader and Swennen, 2004b;

952 Nader, 2014; Hawie et al., 2014). Although the expected source-reservoir 
953 configurations differ between the Bekaa valley and Mount Lebanon, they have

954 been grouped into one domain. They both are believed to contain a good

955 thermogenic system (Bou Daher et al., 2016) in which the Triassic petroleum

956 system is dominant. In the Bekaa, a working Cretaceous petroleum system might

957 also be effective beneath the quaternary cover (e.g. Nader, 2014; Beydoun,

958 1977).

959

960 Four petroleum system charts have been compiled for the Lattakia, deep basin,

961 margin and onshore domains (figs. 15-16). They show the variable petroleum

962 system elements expected in each. The reservoirs, seals, traps and source rock

963 maturity have been discussed in previous sections and are summarized in each

964 chart. In the Lattakia ridge domain and the Levant margin, a mixed

965 thermogenic/biogenic charge is feeding the reservoirs as of the Late Cretaceous

966 to modern time, while in the deep basin a dominantly biogenic system is

967 expected. Onshore, only thermogenic sources are active and charging the

968 reservoirs as of the late Tertiary.

969 Regional analogues

970

971 Comparison between structures and facies documented both offshore and

972 onshore Lebanon draws similarities between the structural style and reservoirs

973 of nearby discoveries and therefore decreases uncertainty. Numerous analogue

974 studies are expected to be carried out in the Levant region in order to bring

975 further knowledge on such an under-drilled and less known basin. Here, we 
976 provide a few insights on the similarities between onshore and probably similar

977 offshore structures.

$\$ 78$

979 The anticlines offshore Beirut (fig. 9) are interpreted to have thin-skinned

980 deformation in which the Eocene unconformity horizon acts as a detachment

981 surface (Ghalayini et al., 2014; Kosi et al., 2012). In the southern Palmyrides, the

982 Triassic salt sequence acts as an effective detachment surface for some of the

983 anticlines in Syria (Brew et al., 2001). One particular example is the Cheriffe

984 anticline (Chaimov et al., 1992) which shows a similar structural style to the

985 offshore Lebanese ones. In addition, some of the anticlines in the Palmyrides

986 have a box-fold geometry, based on subsurface data and surface expression

987 (Searle, 1994) drawing analogies to the Qartaba anticline onshore. The latter has

988 very steep to overturned flanks locally with a gently westward dipping top. This

989 suggests that the Qartaba anticline is not simply a horst as it was commonly

990 referred to (Dubertret, 1955) but a compressional structure with possible fault-

991 propagation folding and/or detachment faulting in which the middle Triassic

992 evaporates could have acted as a decoupling horizon. In fact, Nader et al. (2016)

993 identified in 2D seismic profiles a deepest horizon in north Lebanon possibly

994 representing the Triassic evaporites and suggested a continuity of the Qartaba

995 structure at depth.

996

997 Although the effect of the Triassic detachment layer is not observed offshore, the

998 Eocene unconformity could possess a similar decoupling effect. Therefore, the

999 thin-skinned anticlines of the Palmyrides are very likely structural analogues for

1000 the offshore anticlines. In addition, both the offshore and Qartaba anticlines are 
1001 cross-cut by the same ENE trending dextral strike-slip faults documented along

1002 the Levant margin (Ghalayini et al., 2017). This increases the structural

1003 similarities of these anticlines and insinuates a similar timing, being in the Late

1004 Miocene prior to the effect of the strike-slip faults (e.g. Ghalayini et al., 2014).

1005

1006 The exploration implications on the structural style of the anticlines is profound 1007 as it affects the subsurface closures and location of faults. The uncertainties are 1008 probably less offshore with the availability of 3D seismic data, but the challenges 1009 persist for onshore anticlines. The adopted structural style helps predicting the 1010 likely location of subsurface traps and directly affects the proper positioning of 1011 the wells during exploration. Therefore, using analogues to help exploration 1012 offshore and onshore Lebanon could be of a great value and would reduce 1013 uncertainty significantly.

1014

1015 Lessons learnt from exploration onshore

1016

1017 In the onshore domain, exploration wells have been drilled with total depths

1018 ranging from 1,421 $\mathrm{m}$ to 3,065 $\mathrm{m}$ (Beydoun and Habib, 1995). The deepest

1019 formations reached range in age from Late Cretaceous to mid-Jurassic. In most of

1020 these wells, the main reservoirs were water-flushed due to erosion leading to

1021 bad and ineffective seals, direct communication with elevated meteoric recharge

1022 areas in the high Lebanon and Anti-Lebanon Mountains, or their proximity to

1023 major faults (Nader and Swennen, 2004a; Beydoun and Habib, 1995). Therefore,

1024 it is clear that prospective units must be pre-Jurassic with petroleum system 
1025 elements similar to the Palmyrides with a probable exception of the Bekaa in

1026 which the Jurassic and some Cretaceous strata are buried deeper and could be

1027 well sealed.

1028

1029 Some of the important lessons acquired for future explorers of the onshore

1030 Lebanon are the followings: (i) most importantly, the wells must reach the most

1031 promising units, being the Lower Triassic reservoirs that are proven in the

1032 Palmyrides and (2) analogues must be used to aid exploration - since no

1033 adequate drilling is available to date. Still hydrocarbon shows were noted in

1034 shallow wells, indicating that a working petroleum system exists. This has also

1035 been observed offshore with the numerous DHI's, gas chimneys and working

1036 petroleum system elements, which are all encouraging additional exploration.

1037

1038 To minimise the risk, it is primordial to use modern techniques to properly

1039 characterise the prospects and choose the best drilling location. These involve

1040 (1) reliable seismic data aided by other geophysical data such as gravity,

1041 magnetic and electrical surveys to image the subsurface at depth, (2) usage of

1042 satellite imagery and remote sensing to carefully map the structure at surface

1043 and draw new geological and facies maps over each prospect, and (3) usage of

1044 new modelling techniques in order to visualise and reconstruct the structure at

1045 depth. These techniques will substantially reduce the risk of the petroleum

1046 prospects in the onshore domain. Promising discoveries can be made if new play

1047 concepts are developed and deeper units are targeted in drilling. 


\section{Conclusions}

1049

1050 Interpretations of key seismic reflection profiles along the Levant margin

1051 offshore Lebanon together with a comprehensive overview based on recently

1052 achieved integrated research projects have resulted inan improved

1053 understanding of the geology of this area and of its petroleum exploration

1054 potential. Four geological domains have been identified, and petroleum system

1055 charts were compiled for each summarizing the main source rocks, reservoirs,

1056 seals and traps:

1057

1058 - The deep basin: characterised by predominantly clastic reservoirs and

1059 dominated by Oligo-Miocene biogenic source rocks. The structural traps

1060 might be late Miocene four-way dip closures and early Miocene tilted fault

1061 blocks,

1062

1063 - The Lattakia Ridge: characterised by dominantly Oligo-Miocene clastic

1064 reservoirs and with a mixed biogenic-thermogenic source rock potential.

1065 The traps are Late Cretaceous four-way dip closures.

1066

1067 - The Levant Margin: characterised by Mesozoic carbonate reservoirs

1068 together with Early Cretaceous and Oligo-Miocene clastics, with

1069 predominantly thermogenic source rocks with possibility of lateral

1070 migration from biogenic source rocks. The traps are mostly stratigraphic.

1071 
1072

1073

1074

1075

1076

1077 Working petroleum systems are very likely present in Lebanon and should be

1078 encouraging to undertake additional exploration and drilling within these four

1079 domains. Several lessons can be taken from the wells onshore, which can be used

1080 to better focus future exploration. Nearby discoveries could provide good

1081 analogue examples for the Lebanese prospects and could help in reducing

1082 uncertainties, namely onshore. Such analogues are likely found in the

1083 Palmyrides, and if considered, could positively impact exploration success.

\section{Acknowledgements}

1085

1086

1087 Ministry of Energy and Water of the Republic of Lebanon for allowing to publish

1088 the seismic lines in this manuscript and their interpretation. Petroleum Geo-

1089 services (PGS) are thanked for their support and fruitful discussions. Editor Chris

1090 Tiratsoo and reviewers [...] are thanked for their constructive reviews and

1091 comments, which enhanced the quality of this manuscript 
1094 BARRIER, É., MACHHOUR, L., and BLAIZOT, M., 2014. Petroleum systems of Syria.

1095 In L. MARLOW, C. KENDALL, and L. YOSE (Eds.), Petroleum systems of the

1096 Tethyan region, AAPG Memoir 106, 335-378.

1097 http://doi.org/10.1036/13431862M1063612

1098

1099 BELLOS, G.S., 2008. Sedimentology and diagenesis of some neocomian-

1100 Barremian rocks (Chouf Formation) southern Lebanon. M.S. thesis, American

1101 University of Beirut, Beirut, Lebanon.

1102

1103 BEN-AVRAHAM, Z., GINZBURG, A., MAKRIS, J., and EPPELBAUM, L., 2002. Crustal

1104 structure of the Levant Basin, eastern Mediterranean. Tectonophysics, 346 (1-2),

1105 23-43. http://doi.org/10.1016/S0040-1951(01)00226-8

1106

1107 BEYDOUN, Z. R., 1977. Petroleum Prospects of Lebanon: Reevaluation. AAPG

1108 Bulletin, 61 (I), 43-64. http://doi.org/10.1306/C1EA3BF4-16C9-11D7-

$1109 \underline{8645000102 C 1865 \mathrm{D}}$

1110

1111 BEYDOUN, Z. R., and HABIB, J. G. 1995. Lebanon revisited: new insights into

1112 Triassic hyrocarbon prospects. Journal of Petroleum Geology, 18 (1), 75-90.

1113

1114 BEYDOUN, Z.R., 1999. Evolution and development of the Levant (Dead Sea Rift)

1115 transform system: a historical- chronological review of a structural controversy.

1116 In: MacNiocaill, C., Ryan, P.D. (Eds.), Continental Tectonics. Geol. Soc. Lond., Spec.

1117 Publ., 164, 239-255 http://doi.org/10.1144/GSL.SP.1999.164.01.12

1118 
1120 BOU DAHER, S., DUCROS, M., MICHEL, P., NADER, F. H., and LITTKE, R., 2016. 3D

1121 thermal history and maturity modelling of the Levant Basin and Margin. Arabian

1122 Journal of Geosciences, 17, 3161. http://doi.org/10.1007/s12517-016-2455-1

1123

1124 BOU DAHER, S., NADER, F. H., MÜLLER, C., and LITTKE, R., 2015. Geochemical

1125 and petrographic characterization of Campanian - Lower Maastrichtian

1126 calcareous petroleum source rocks of Hasbayya, South Lebanon. Marine and

1127 Petroleum Geology, 64, 304-323.

1128 http://doi.org/10.1016/j.marpetgeo.2015.03.009

1129

1130 BOU DAHER, S., NADER, F. H., STRAUSS, H., and LITTKE, R., 2014. Depositional

1131 environment and source-rock characterisation of organic-matter rich Upper

1132 Santonian-Upper Campanian carbonates, northern Lebanon. Journal of Petroleum

1133 Geology, 37, 5-24.

1134

1135 BREW, G. E., BARAZANGI, M., AL-MALEH, A. K., and SAWAF, T., 2001. Tectonic

1136 and Geologic Evolution of Syria. GeoArabia, 6 (4), 573-616.

1137

1138 BUTLER, R. W. H., SPENCER, S., and GRIFFITHS, H. M., 1998. The structural

1139 response to evolving plate kinematics during transpression: evolution of the

1140 Lebanese restraining bend of the Dead Sea Transform. In Holdsworth, R.E.,

1141 Strachan, R.A., Dewey, J.F. (Eds.), Continental transpressional and transtensional

1142 tectonics, Geol. Soc. Lond., Spec. Publ. 135, 81-106.

1143 (doi.org/10.1144/GSL.SP.1998.135.01.06) 
1145 CARTWRIGHT, J. A., 2011. Diagenetically induced shear failure of fine-grained

1146 sediments and the development of polygonal fault systems. Marine and

1147 Petroleum Geology, 28 (9), 1593-1610.

1148 (http://doi.org/10.1016/j.marpetgeo.2011.06.004)

1150 CHAIMOV, T. A., BARAZANGI, M., AL-SAAD, D., SAWAF, T., and GEBRAN, A., 1992.

1151 Mesozoic and Cenozoic deformation inferred from seismic stratigraphy in the

1152 southwestern intracontinental Palmyride fold-thrust belt, Syria. Geological

1153 Society of America Bulletin, 104 (6), 704-715

1154 (doi.org/10.1130/0016-7606(1992)104<0704:MACDIF>2.3.CO;2)

1155

1156 CHAIMOV, T. A., BARAZANGI, M., AL-SAAD, D., SAWAF, T., and KHADDOUR, M. 1157 (1993). Seismic fabric and 3-D structure of the southwestern intracontinental 1158 Palmyride fold belt, Syria. AAPG Bulletin, 77 (12), 2032-2047.

1159

1160 DAËRON, M., BENEDETTI, L., TAPPONNIER, P., SURSOCK, A. and FINKEL, R.C.,

1161 2004. Constraints on the post $~ 25$-ka slip rate of the Yammoûneh fault

1162 (Lebanon) using in situ cosmogenic 36Cl dating of offset limestone-clast fans:

1163 Earth and Planetary Science Letters, 227, 105-119.

1164 (doi:10.1016/j.epsl.2004.07.014)

1165

1166 DAVIES, R. J., IRELAND, M. T., and CARTWRIGHT, J. A., 2009. Differential

1167 compaction due to the irregular topology of a diagenetic reaction boundary : a 1168 new mechanism for the formation of polygonal faults. Basin Research, 21, 354- 
1169

359. (doi.org/10.1111/j.1365-2117.2008.00389.x)

1170

1171 DOLSON, J. C., BOUCHER, P. J., SIOK, J., and HEPPARD, P. D., 2005. Key Challenges

1172 to realizing full potential in an emerging giant gas province: Nile

1173 Delta/Mediterranean offshore, deep water, Egypt. In Doré, A. G., Vining, B.A.

1174 (Eds.), Petroleum Geology: North-West Europe and Global Perspectives -

1175 Proceedings of the 6th Petroleum geology conference, Petroleum Geology

1176 Conferences, 607-624. (doi.org/897.553)

1177

1178 DUBERTRET, L., 1955. Carte géologique du Liban au 1/200000 avec notice

1179 explicative: Beirut, République Libanaise, Ministère des Travaux Publiques, 74

1180 pp.

1181

1182 ESESTIME, P., HEWITT, A., and HODGSON, N., 2016. Zohr - A newborn carbonate

1183 play in the Levantine Basin, East-Mediterranean. First Break, 34, 87-93.

1184

1185 FEINSTEIN, S., AIZENSHTAT, Z., MILOSLAVSKI, I., GERLING, P., SLAGER, J., and

1186 MCQUILKEN, J., 2002. Genetic characterization of gas shows in the east

1187 Mediterranean offshore of southwestern Israel. Organic Geochemistry, 33 (12),

1188 1401-1413. (doi.org/10.1016/S0146-6380(02)00184-5)

1189

1190 FREUND, R., GARFUNKEL, Z., ZAK, I., GOLDBERG, M., WEISSBROD, T., DERIN, B.,

1191 ... GIRDLER, R. W. (1970). The Shear along the Dead Sea Rift [and Discussion].

1192 Philosophical Transactions of the Royal Society A: Mathematical, Physical and

1193 Engineering Sciences, 267 (1181), 107-130. (doi.org/10.1098/rsta.1970.0027) 
1195 FRIZON DE LAMOTTE, D., RAULIN, C., MOUCHOT, N., CHRISTOPHE, J., DAVEAU, 1196 W., BLANPIED, C., and RINGENBACH, J. C. (2011). The southernmost margin of 1197 the Tethys realm during the Mesozoic and Cenozoic : Initial geometry and timing 1198 of the inversion processes. Tectonics, 30,1-22.

1199 (doi.org/10.1029/2010TC002691)

1200

1201 GARDOSH, M. and DRUCKMAN, Y., 2006. Seismic strati- graphy, structure and 1202 tectonic evolution of the Levantine basin, offshore Israel. In: A.H.F. Robertson 1203 and D. Mountrakis, (Eds.), Geol. Soc. Lond., Spec. Publ., 260, 201 - 227.

1204

1205 GARDOSH, M., DRUCKMAN, Y., BUCHBINDER, B. and CALVO, R., 2008. The Oligo1206 Miocene deepwater system of the Levant Basin. Geological survey of Israel, 33, 1$1207 \quad 73$.

1208

1209 GARDOSH, M. A., GARFUNKEL, Z., DRUCKMAN, Y. and BUCHBINDER, B., 2010.

1210 Tethyan rifting in the Levant Region and its role in Early Mesozoic crustal

1211 evolution. In: Homberg C. and Bachmann M. (Eds), Evolution of the Levant

1212 Margin and Western Arabia Platform since the Mesozoic. Geol. Soc. Lond., Spec.

1213 Publ., 341, 9 - 36.

1214

1215 GARDOSH, M., WEIMER, P., and FLEXER, A., 2011. The sequence stratigraphy of 1216 Mesozoic successions in the Levant margin, southwestern Israel: A model for the 1217 evolution of southern Tethys margins. AAPG Bulletin, 95 (10), 1763-1793.

1218 (doi.org/10.1306/02081109135) 
1220 GARDOSH, M., and TANNENBAUM, E., 2014. Petroleum systems of Israel. In L.

1221 MARLOW, C. KENDALL, and L. YOSE (Eds.), Petroleum systems of the Tethyan

1222 region, $A A P G$ Memoir 106, 179-216.

1223

1224

1225 GARFUNKEL, Z., 1998. Constrains on the origin and history of the Eastern

1226 Mediterranean basin. Tectonophysics, 298 (1-3), 5-35. (doi.org/10.1016/S0040-

1227 1951(98)00176-0)

1228

1229

GEDEON, M., 1999. Structural analysis of latitudinal faults in the Mount Lebanon

1230 north of Beirut: their kinematic and their role in the tectonic evolution of

1231 Lebanon. Master's thesis, American University of Beirut, Beirut, Lebanon.

1232

1233 GHALAYINI, R., DANIEL, J.-M., HOMBERG, C., NADER, F. H., and COMSTOCK, J. E., 1234 2014. Impact of Cenozoic strike-slip tectonics on the evolution of the northern

1235 Levant Basin (offshore Lebanon). Tectonics, 33 (11), 2121-2142.

1236 (doi.org/10.1002/2014TC003574)

1237

1238 GHALAYINI, R., HOMBERG, C., DANIEL, J.-M., and NADER, F. H., 2016. Growth of 1239 layer-bound normal faults under a regional anisotropic stress field. In Childs, c., 1240 Holdsworth, R.E., Jackson, C.A.L, Manzocchi, T., Walsh, J.J., Yielding, G. The

1241 Geometry an Growth of normal faults. Geol. Soc. Lond., Spec. Publ. 439.

1242 (doi.org/10.1144/SP439.13) 
1244 GHALAYINI, R., DANIEL, J., HOMBERG, C., NADER, F. H., DARNAULT, R., MENGUS,

1245 J., and BARRIER, E., 2017. The effect of the Palmyra trough and Mesozoic

1246 structures on the Levant margin and on the evolution of the Levant Restraining

1247 bend. In Roure, F., Amin, A., Khomsi, S., Al-Garni, M.A.M. (Eds.), Lithosphere

1248 dynamics and sedimentary basins of the Arabian plate and surrounding areas,

1249 Springer, 149-172. (doi.org/10.1007/978-3-319-44726-1)

1250

1251 GOMEZ, F., KHAWLIE, M., TABET, C., DARKAL, A. N., KHAIR, K., and BARAZANGI,

1252 M., 2006. Late Cenozoic uplift along the northern Dead Sea transform in Lebanon

1253 and Syria. Earth and Planetary Science Letters, 241 (3-4), 913-931.

1254 (doi.org/10.1016/j.epsl.2005.10.029)

1255

1256 GOMEZ, F., MEGHRAOUI, M., DARKAL, A. N., SBEINATI, R., DARAWCHEH, R.,

1257 TABET, C., KHAIR, K. and BARAZANGI, M., 2001. Coseismic displacements along

1258 the Serghaya fault: an active branch of the Dead Sea fault system in Syria and

1259 Lebanon. Journal of the Geological Society, 158, 405-408.

1260

1261 GORINI, C., MONTADERT, L., and RABINEAU, M., 2015. New imaging of the

1262 salinity crisis: Dual Messinian lowstand megasequences recorded in the deep

1263 basin of both the eastern and western Mediterranean. Marine and Petroleum

1264 Geology, 1-17. (doi.org/10.1016/j.marpetgeo.2015.01.009)

1265

1266 HALL, J. T., CALON, T. J., AKSU, A. E., and MEADE, S. R., 2005. Structural evolution

1267 of the Latakia Ridge and Cyprus Basin at the front of the Cyprus Arc, Eastern

1268 Mediterranean Sea. Marine Geology, 221, 261-297. 
1269 (doi.org/10.1016/j.margeo.2005.03.007)

1270

1271 HANCOCK, P. L., and ATIYA, M. S., 1979. Tectonic significance of mesofracture

1272 systems associated with the Lebanese segment of the Dead Sea transform fault.

1273 Journal of Structural Geology, 1 (2), 143-153. (doi.org/10.1016/0191-

1274 8141(79)90051-8)

1275

1276 HAQ, B. U., and AL-QAHTANI, A. M., 2005. Phanerozoic cycles of sea-level change

1277 on the Arabian Platform Rationale for an Arabian Platform Cycle Chart.

1278 GeoArabia, 10 (2), 127-160.

1279

1280 HAWIE, N., GORINI, C., DESCHAMPS, R., NADER, F.H., MONTADERT, L.,

1281 GRANJEON, D., and BAUDIN, F., 2013. Tectono-stratigraphic evolution of the

1282 northern Levant Basin (offshore Lebanon). Mar. Pet. Geo., (doi: 10.1016:j.

1283 marpetgeo.2013.08.004)

1284

1285 HAWIE, N., DESCHAMPS, R., NADER, F.H., GORINI, C., MÜLLER, C., DESMARES, D., 1286 HOTEIT, A., GRANJEON, D., MONTADERT, L. and BAUDIN, F., 2014.

1287 Sedimentologic and stratigraphic evolution of northern Lebanon since the Late

1288 Cretaceous: implications on the Levant margin and basin. Arabian Journal of

1289 Geosciences (DOI: 10.1007/s12517-013-0914-5)

1290

1291 HAWIE, N., DESCHAMPS, R., GRANJEON, D., NADER, F.H., GORINI, C., MULLER, C.,

1292 MONTADERT, L. and BAUDIN, F., 2015. Multi-scale constraints of sediment

1293 source to sink systems in frontier basins: a forward stratigraphic modeling case 
1294 study of the Levant region. Basin Research 1-28, doi: 10.1111/bre.12156

1295

1296 HOMBERG, C., BARRIER, É., MROUEH, M., HAMDAN, W., and HIGAZI, F., 2009.

1297 Basin tectonics during the Early Cretaceous in the Levant margin, Lebanon.

1298 Journal of Geodynamics, 47 (4), 218-223. (doi.org/10.1016/j.jog.2008.09.002)

1299

1300 HOMBERG, C., BARRIER, É., MROUEH, M., MÜLLER, C., HAMDAN, W., and HIGAZI,

1301 F., 2010. Tectonic evolution of the central Levant domain (Lebanon) since

1302 Mesozoic time. In Homberg, C. and Bachmann, M. (Eds.), Evolution of the Levant

1303 margin and western Arabia platform since the Mesozoic, Geol. Soc. Lond., Spec.

1304 Publ., 341, 245-268. (doi.org/10.1144/SP341.12)

1305

1306 INATI, L., ZEYEN, H., NADER, F. H., ADELINET, M., SURSOCK, A., ELIE, M., and

1307 ROURE, F., 2016. Lithospheric architecture of the Levant Basin (Eastern

1308 Mediterranean region): A 2D modeling approach. Tectonophysics, 693, 143-156.

1309 (doi.org/10.1016/j.tecto.2016.10.030)

1310

1311 KHAIR, K., KHAWLIE, M., HADDAD, F., BARAZANGI, M., SEBER, D., and CHAIMOV,

1312 T. A., 1993. Bouguer gravity and crustal structure of the Dead Sea transform fault

1313 and adjacent mountain belts in Lebanon. Geology, 21, 739-742.

1314

1315 KOSI, W., TARI, G., NADER, F. H., SKIPLE, C., TRUDGILL, B. D., and LAZAR, D.,

1316 2012. Structural analogy between the "piano key faults" of deep-water Lebanon

1317 and the extensional faults of the Canyonlands grabens, Utah, United States. The

1318 Leading Edge, (July), 824-830. 
1320 LE PICHON, X., and GAULIER, J. M., 1988. The rotation of Arabia and the Levant 1321 fault system. Tectonophysics, 153 (1-4), 271-294. (doi.org/10.1016/00401322 1951(88)90020-0)

1324 LE PICHON, X., and KREAMER, C., 2010. The Miocene-to-Present Kinematic 1325 Evolution of the Eastern Mediterranean and Middle East and Its Implications for 1326 Dynamics. Annual Review of Earth and Planetary Science, 38, 323-351.

1327 (doi.org/10.1146/annurev-earth-040809-152419)

LUNING, S., and KUSS, J., 2014. Petroleum Geology of Jordan. In L. MARLOW, C. 1330 KENDALL, and L. YOSE (Eds.), Petroleum systems of the Tethyan region, $A A P G$ 1331 Memoir 106, 149-172.

1333 MAKRIS, J., BEN-AVRAHAM, Z., BEHLE, A., GINZBURG, A., GIESE, P., STEINMETZ, 1334 L., ... ELEFTHERIOU, S., 1983. Seismic refraction profiles between Cyprus and 1335 Israel and their interpretation. Geophysical Journal International, 75, 575-591.

1337 MAKSOUD, S., RANIER, B.G., AZAR, D., GEZE, R., PAICHELER, J.P. and MORENO1338 BEDMAR, J., 2014. Revision of 'Falaise de B LANCHE' ( Lower Cretaceous ) in 1339 Lebanon, with the definition of a Jezzinian Regional Stage: Carnets de Geologie, $1340 \quad \mathbf{1 4}, 401-427$.

1342 MONTADERT, L., NICOLAIDES, S., SEMB, P. H., and LIE, O. (2014). Petroleum

1343 Systems offshore Cyprus. In L. MARLOW, C. KENDALL, and L. YOSE (Eds.), 
1344 Petroleum systems of the Tethyan region, AAPG Memoir 106, 301-334.

1345 MONTADERT, L., SEMB, P. H., LIE, O., and KASSINIS, S., 2010. New seismic may

1346 put offshore Cyprus hydrocarbon prospects in the spotlight. First Break, 28

1347 (April), 91-101.

1348

1349 MÜLLER, C., HIGAZI, F., HAMDAN, W., and MROUEH, M., 2010. Revised

1350 stratigraphy of the Upper Cretaceous and Cenozoic series of Lebanon based on

1351 nannofossils. In Homberg, C. and Bachmann, M. (Eds.), Evolution of the Levant

1352 margin and western Arabia platform since the Mesozoic, Geol. Soc. Lond., Spec.

1353 Publ., 341, 287-303. (doi.org/10.1144/SP341.14)

1354

1355 NADER, F. H., and SWENNEN, R., 2004a. Petroleum prospects of Lebanon: some

1356 remarks from sedimentological and diagenetic studies of Jurassic carbonates.

1357 Marine and Petroleum Geology, 21 (4), 427-441. (doi.org/10.1016/S0264-

1358 8172(03)00095-3)

1359

1360 NADER, F. H., and SWENNEN, R., 2004b. The hydrocarbon potential of Lebanon:

1361 new insights from regional correlations and studies of Jurassic dolimitization.

1362 Journal of Petroleum Geology, 27 (3), 253-275.

1363

1364 NADER, F. H., 2011. The petroleum prospectivity of Lebanon: an overview.

1365 Journal of Petroleum Geology, 34, 135-156.

1366

1367 NADER, F. H., 2014. Insights into the petroleum prospectivity of Lebanon. In L.

1368 MARLOW, C. KENDALL, and L. YOSE (Eds.), Petroleum systems of the Tethyan 


\section{9}

region, $A A P G$ Memoir 106, 241-278. (doi.org/10.1036/13431859M1063609)

1370

1371 NADER, F. H., BROWNING-STAMP, P., and LECOMTE, J. C., 2016. Geological

1372 intepretation of 2D seismic reflection profiles onshore Lebanon: implications for

1373 petroleum exploration. Journal of Petroleum Geology, 39, 333-356.

1374

1375 NETZEBAND, G., GOHL, K., HÜBSCHER, C., BEN-AVRAHAM, Z., DEHGHANI, G. A., 1376 GAJEWSKI, D., and LIERSCH, P., 2006. The Levantine Basin-crustal structure 1377 and origin. Tectonophysics, 418 (3-4), 167-188.

1378 (doi.org/10.1016/j.tecto.2006.01.001)

1380 QUENNELL, A. M., 1984. The Western Arabia rift system. In R. J. Dixon, R.J., 1381 Robertson, A.H.F. (Eds.), The geological evolution of the Eastern Mediterranean, 1382 Geol. Soc. Lond., Spec. Publ., 17, 775-788.

1383 (doi.org/10.1144/GSL.SP.1984.017.01.62)

1384

1385 RENOUARD, G., 1955. Oil prospects of Lebanon. AAPG Bulletin, 39 (11), 212513862169.

1387

1388 ROBERTS, G., and PEACE, D., 2007. Hydrocarbon plays and prospectivity of the 1389 Levantine Basin, offshore Lebanon and Syria from modern seismic data.

1390 GeoArabia, 12 (3).

1391

1392 ROBERTSON, A. H. F., 1998. Tectonic significance of the Eratosthenes Seamount:

1393 a continental fragment in the process of collision with a subduction zone in the 
1394 eastern Mediterranean (Ocean Drilling Program Leg 160). Tectonophysics, 298

1395 (1-3), 63-82. (doi.org/10.1016/S0040-1951(98)00178-4)

1396

1397 ROBERTSON, A. H. F., DIXON, J. E., BROWN, S., COLLINS, A., MORRIS, A. P., 1398 PICKETT, E., ... USTAOMER, T., 1996. Alternative tectonic models for the Late 1399 Palaeozoic-Early Tertiary development of Tethys in the Eastern Mediterranean 1400 region. In Morris, A., Tarling, D.H. (Eds.), Palaeomagnetism and tectonics of the 1401 Mediterranean region. Geol. Soc. Lond., Spec. Publ., 105, 239-263.

1402 (doi.org/10.1144/GSL.SP.1996.105.01.22)

1403

1404 SAWAF, T., BREW, G. E., LITAK, R. K., and BARAZANGI, M., 2001. Geologic 1405 evolution of the intraplate palmyride basin and euphrates fault system syria. In 1406 P. A. Ziegler, P.A, Cavazza, W., Robertson, A.H.F., Crasquin-Soleau, S. (Eds.), Peri1407 Tethys Memoir 6: Peri-Tethyan rift/Wrench basins and passive margins, 1408 Memoire du Museum national d'histoire naturelle, Paris,, 441-467).

1409 SEARLE, M.P., 1994. Structure of the intraplate eastern Palmyride fold belt, Syria:

1410 Geological Society of America Bulletin, 106, 1332-1350. (doi: 10.1130/0016-

$14117606(1994) 106<1332)$

1412

1413 SENGOR, A. M. C., and YILMAZ, Y., 1981. Tethyan evolution of Turkey: a plate 1414 tectonic approach. Tectonophysics, 75, 181-241.

1415

1416 SHENHAV, H., 1971. Lower Cretaceous Sandstone Reservoirs, Israel:

1417 Petrography, Porosity, Permeability. AAPG Bulletin, 55 (12), 2194-2224.

1418 (doi.org/10.1306/819A3E30-16C5-11D7-8645000102C1865D) 
1420 STAMPFLI, G. M., and HOCHARD, C., 2009. Plate tectonics of the Alpine realm. In

1421 Murphy, J.B., Keppie, J.D., Hynes, A.J. (Eds.), Ancient orogens and modern

1422 analogues, Geol. Soc. Lond., Spec. Publ. 327, 89-111( doi.org/10.1144/SP327.6)

1423

1424 STEINBERG, J., GVIRTZMAN, Z., FOLKMAN, Y., and GARFUNKEL, Z., 2011. Origin

1425 and nature of the rapid late Tertiary filling of the Levant Basin. Geology, 39 (4),

1426 355-358. (doi.org/10.1130/G31615.1)

1427

1428 SYMEOU, V., HOMBERG, C., NADER, F.H., DARNAULT, R., LECOMTE, J.C. \&

1429 PAPADIMITRIOU, N. In review. Longitudinal and temporal evolution of the

1430 tectonic style along the Cyprus Arc system, assessed through 2D reflection

1431 seismic interpretation.

1432

1433 WALLEY, C.D., 1997. The lithostratigraphy of Lebanon: a Review. Lebanese

1434 Scientific Bulletin, 10, 81-108

1435

1436 WALLEY, C.D., 1998. Some outstanding issues in the geology of Lebanon and

1437 their importance in the tectonic evolution of the Levantine region.

1438 Tectonophysics, 298, 37-62.

1439

1440 WETZEL, R., 1974. Etapes de la prospection petroliere en Syrie et au Liban

1441 (Notes et mémoires). Compagnie Francaise des Petroles, Paris.

1443 WRONA, T., JACKSON, C. A., HUUSE, M., and TAYLOR, K. G., 2015. Silica diagenesis 
1444 in Cenozoic mudstones of the NorthViking Graben : physical properties and basin

1445 modelling. Basin Research, 1-20. (doi.org/10.1111/bre.12168)

1446

1447

1448 Figures

1449

1450 Fig1: Main structural elements of Lebanon, the Levant Basin and part of Syria. Map

1451 compiled from Barrier et al. 2014; Ghalayini et al. 2016; Ghalayini et al. 2014; Brew

1452 et al. 2001.

1453

1454 fig. 2: Creaming curve for both the Oligo-Miocene 4-way dip closures and the

1455 Mesozoic carbonate plays in the Levant Basin.

1456

1457 Fig. 3: Geo-seismic line showing the Levant margin off the coast of northern Lebanon

1458 consisting mainly of a carbonate succession. The Triassic contains extensional

1459 normal faults in relation to the Triassic breakup of Pangea and the Early Cretaceous

1460 clastics are pinching out on the Jurassic carbonate talus deposits.

1461

1462 Fig. 4: Structural map of the Saida-Tyr plateau offshore and the onshore Tyr-

1463 Nabatieh plateau. The depth map offshore corresponds to the Senonian

1464 unconformity horizon. The en-echelon anticlines along the Saida fault are only

1465 observed at the Base Messinian horizon and not at the level of the Senonian

1466 unconformity.

1467

1468 Fig. 5: Geo-seismic line showing the Levant margin off the coast of southern 
1469 Lebanon. The broad Mesozoic platform in this area is referred to as the Saida-Tyr

1470 Plateau (Ghalayini et al. 2014). The seismic data was tied to the nearby Adloun well

1471 and shows the complete Jurassic to Cretaceous succession found onshore. The

1472 strong reflectors below the Jurassic are believed to represent the Triassic. For

1473 location, see figure 4.

1474

1475 Fig. 6: Geoseismic line across the western edge of the Saida-Tyr plateau showing

1476 the transgressive anticlines separating the deep basin from the Mesozoic plateau.

1477 For location, see figure 4.

1478

1479 Fig 7: The geological domains of Lebanon together with the nearby hydrocarbon

1480 discoveries

1481

1482 Fig. 8: Petroleum potential, stratigraphy and tectonic events for Lebanon and its

1483 offshore

1484

1485 Fig. 9: An example of a NE trending anticline in the deep basin domain offshore

1486 Lebanon. The structural style suggests detachment folding on an intra-Eocene

1487 horizon. The anticlines were folded in the Late Miocene prior to the Messinian event

1488 (Ghalayini et al. 2014).

1489

1490 Fig 10: Seismic section showing the titled fault blocks in the deep basin domain. The

1491 depth map of the base mid Miocene horizon shows the geometry of the associated

1492 traps at present day

1494 Fig. 11: Geo-seismic line showing the Latakia Ridge north of the Levant Basin 
1496 Flg. 12: gas chimneys on top of a Miocene anticline observed only when the

1497 Messinian seal thins or is absent. The overlying Pliocene exhibits numerous bright

1498 spots and DHI's pointing to entrapment of the leaked gas into Pliocene reservoirs in 1499 structural closures.

1500

1501 Fig. 13: Geoseismic line showing a bright spot and a potential flat spot in the Lower

1502 Cretaceous unit pinching out along the Levant margin and trapped between

1503 Mesozoic carbonates.

1504

1505 Fig. 14: Geoseismic line showing a potential flat spot in the Oligocene unit observed

1506 along the Levant margin. The lateral Oligo-Miocene units are pinching out on the

1507 margin forming classical stratigraphic traps.

1508

1509 Fig. 15: Petroleum system charts for the deep basin and Latakia Ridge domains.

1510

1511 Fig. 16: Petroleum system charts for the Levant margin and onshore domains. 


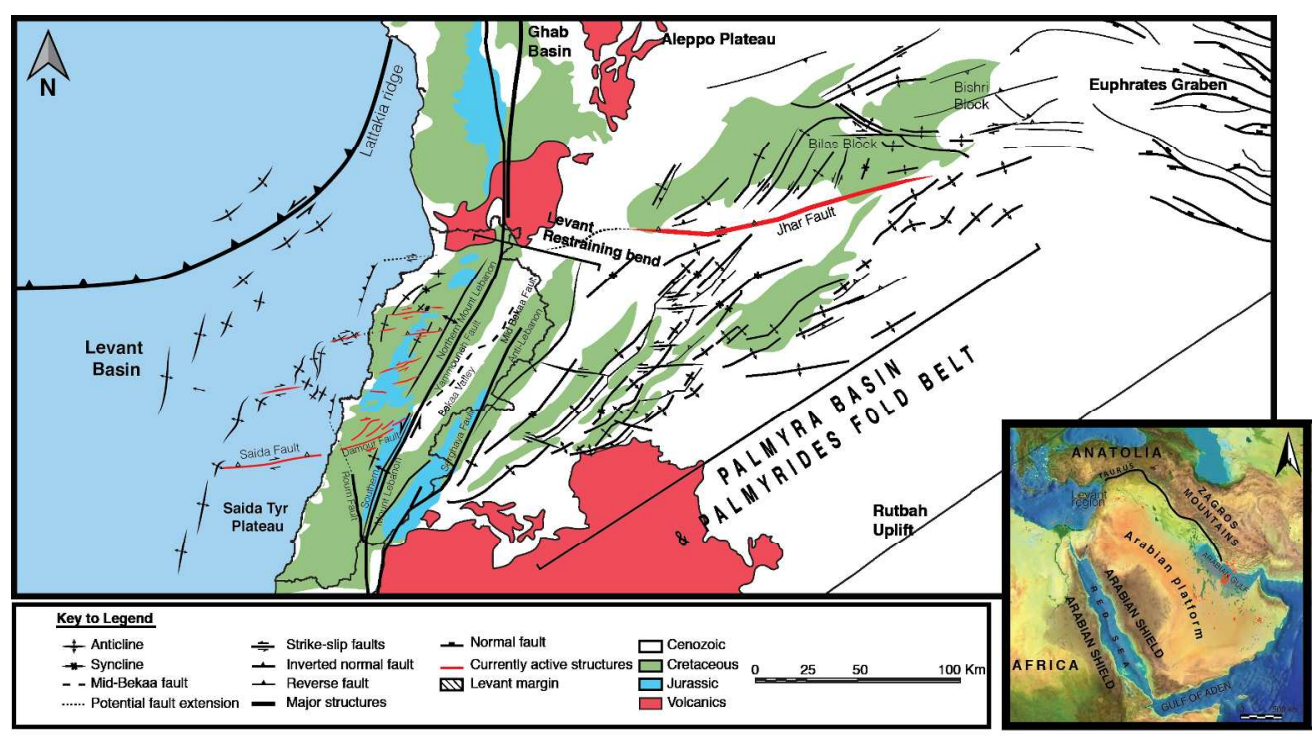

\section{Figure 1}

Main structural elements of Lebanon, the Levant Basin and part of Syria. Map compiled from Barrier et al. 2014; Ghalayini et al. 2016; Ghalayini et al. 2014; Brew et al. 2001. 


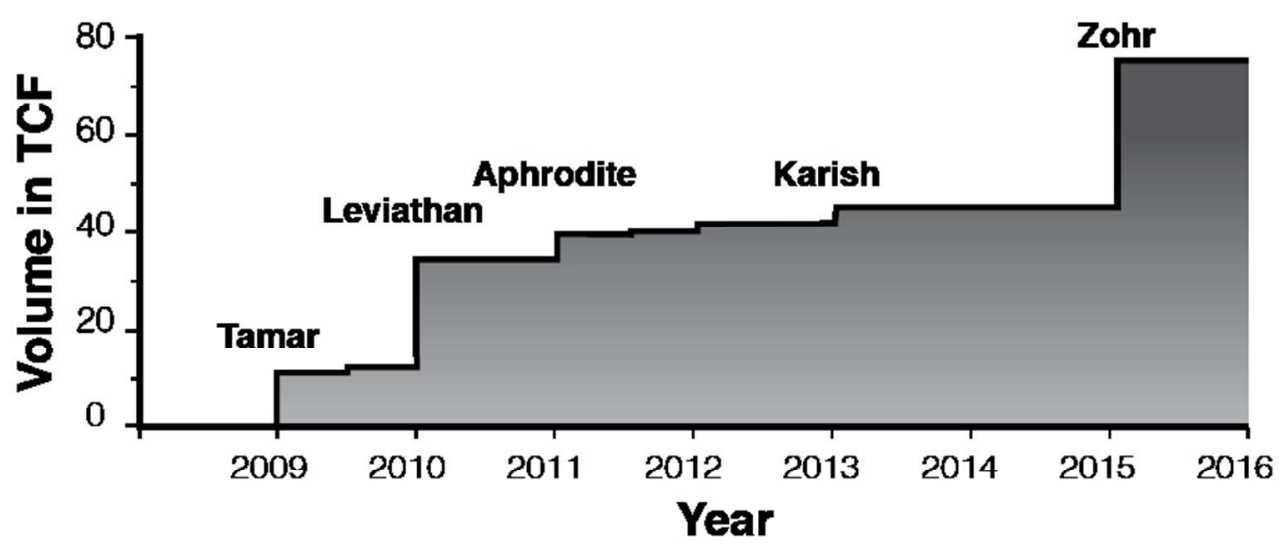

\section{Figure 2}

Creaming curve for both the Oligo-Miocene 4-way dip closures and the Mesozoic carbonate plays in the Levant Basin. 

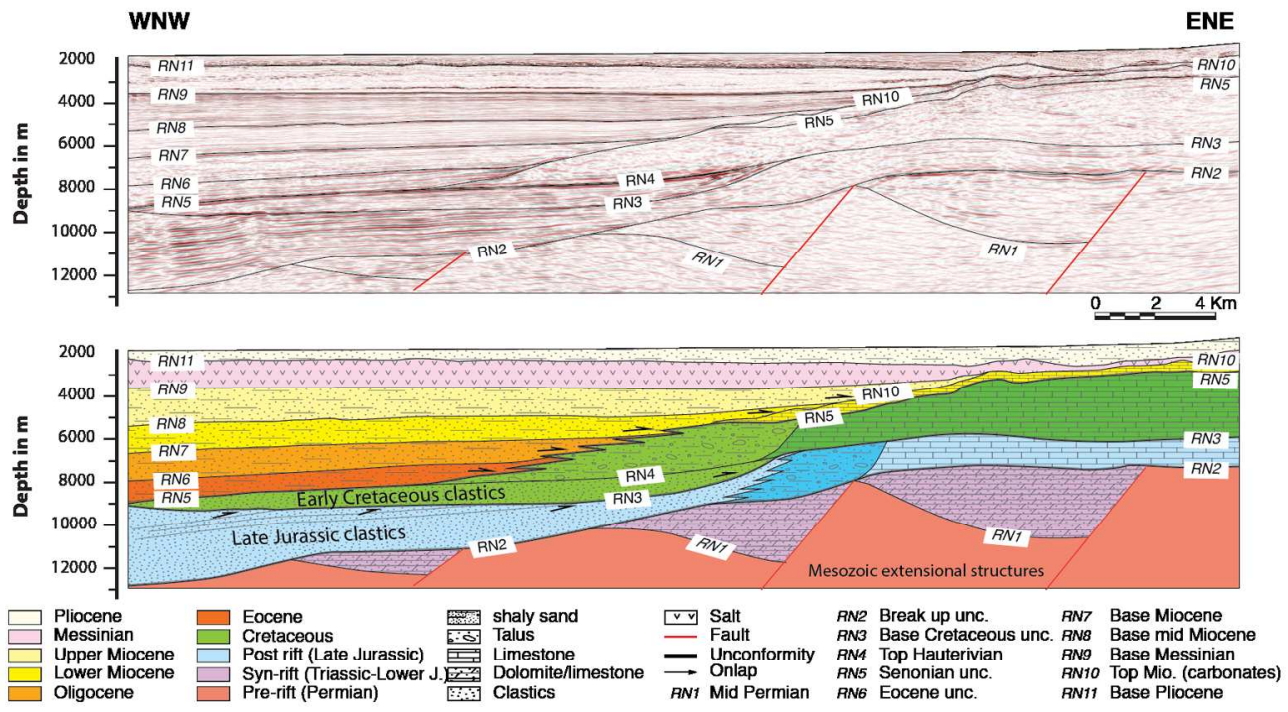

Figure 3

Geo-seismic line showing the Levant margin off the coast of northern Lebanon consisting mainly of a carbonate succession. The Triassic contains extensional normal faults in relation to the Triassic breakup of Pangea and the Early Cretaceous clastics are pinching out on the Jurassic carbonate talus deposits. 


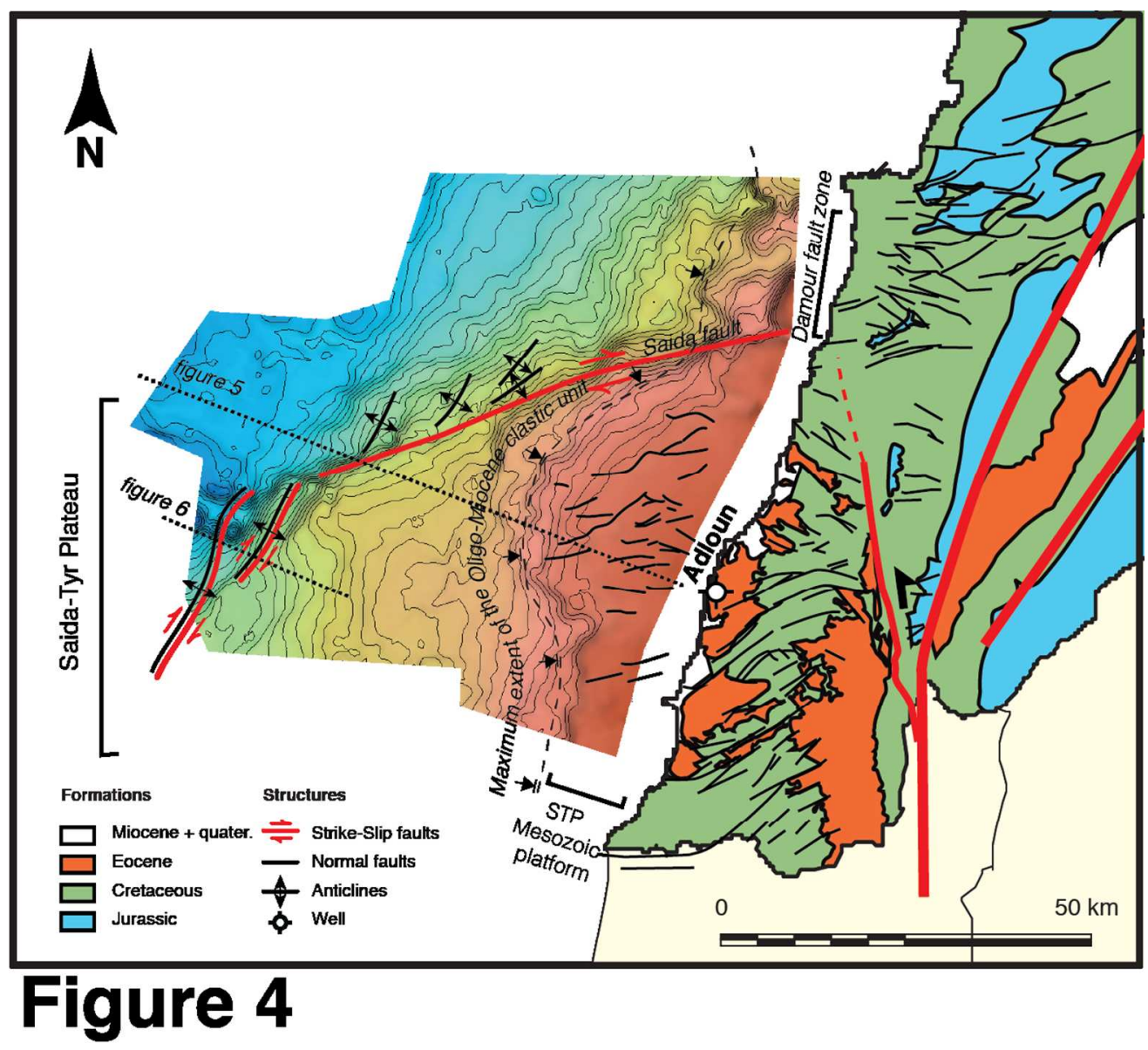

Structural map of the Saida-Tyr plateau offshore and the onshore Tyr-Nabatieh plateau. The depth map offshore corresponds to the Senonian unconformity horizon. The en-echelon anticlines along the Saida fault are only observed at the Base Messinian horizon and not at the level of the Senonian unconformity. 
Geo-seismic line showing the Levant margin off the coast of southern Lebanon. The broad Mesozoic platform in this area is referred to as the Saida-Tyr Plateau (Ghalayini et al. 2014). The seismic data was tied to the nearby Adloun well and shows the complete Jurassic to Cretaceous succession found onshore. The strong reflectors below the Jurassic are believed to represent the Triassic. For location, see figure 4. 


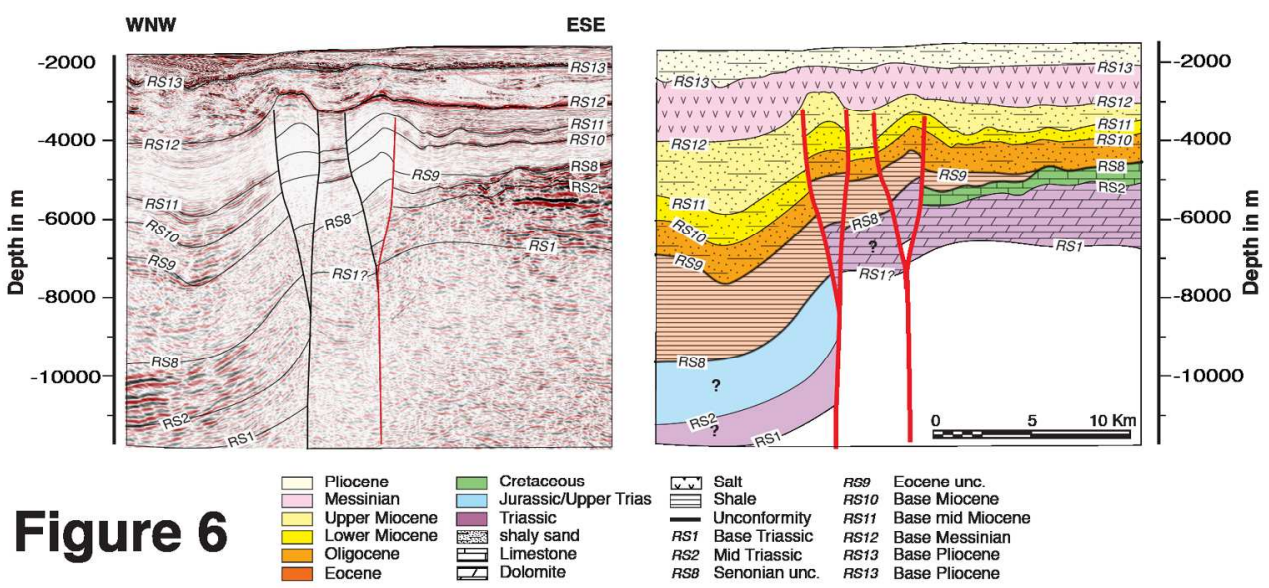

Geoseismic line across the western edge of the Saida-Tyr plateau showing the transgressive anticlines separating the deep basin from the Mesozoic plateau. For location, see figure 4. 
Page 69 of 78

Journal of Petroleum Geology

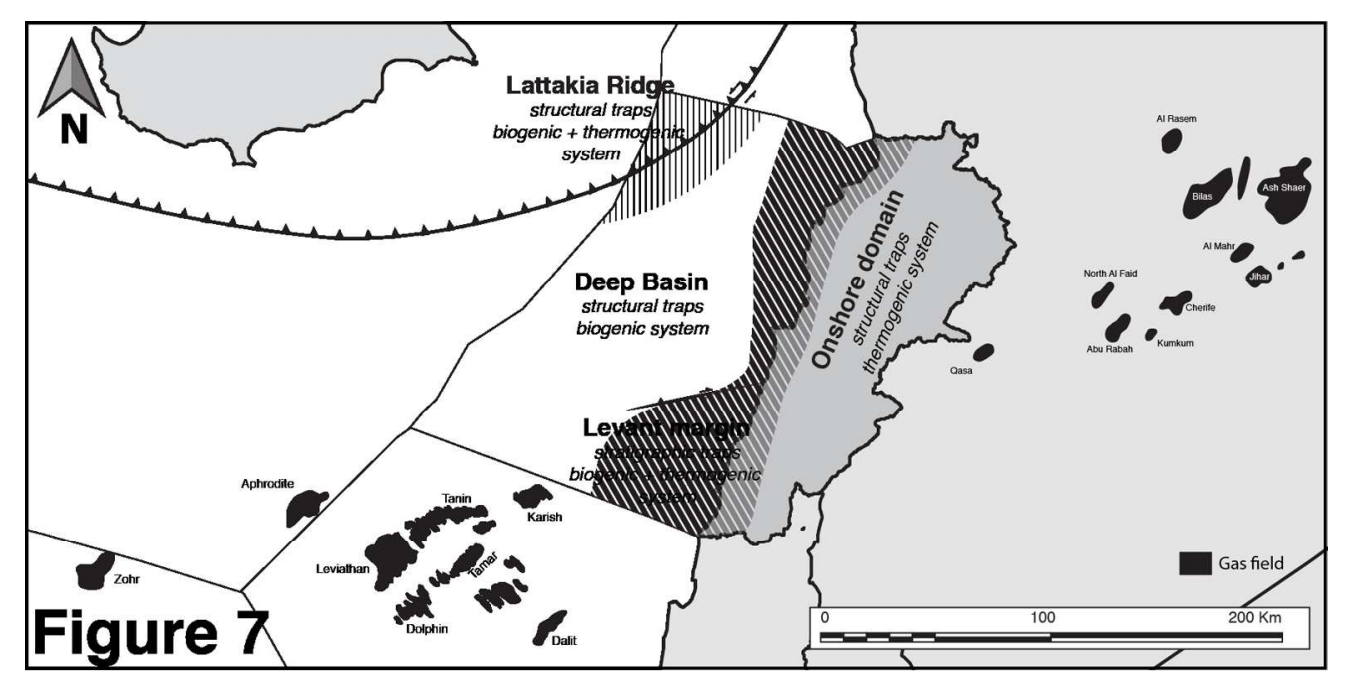

The geological domains of Lebanon together with the nearby hydrocarbon discoveries.

For review only 


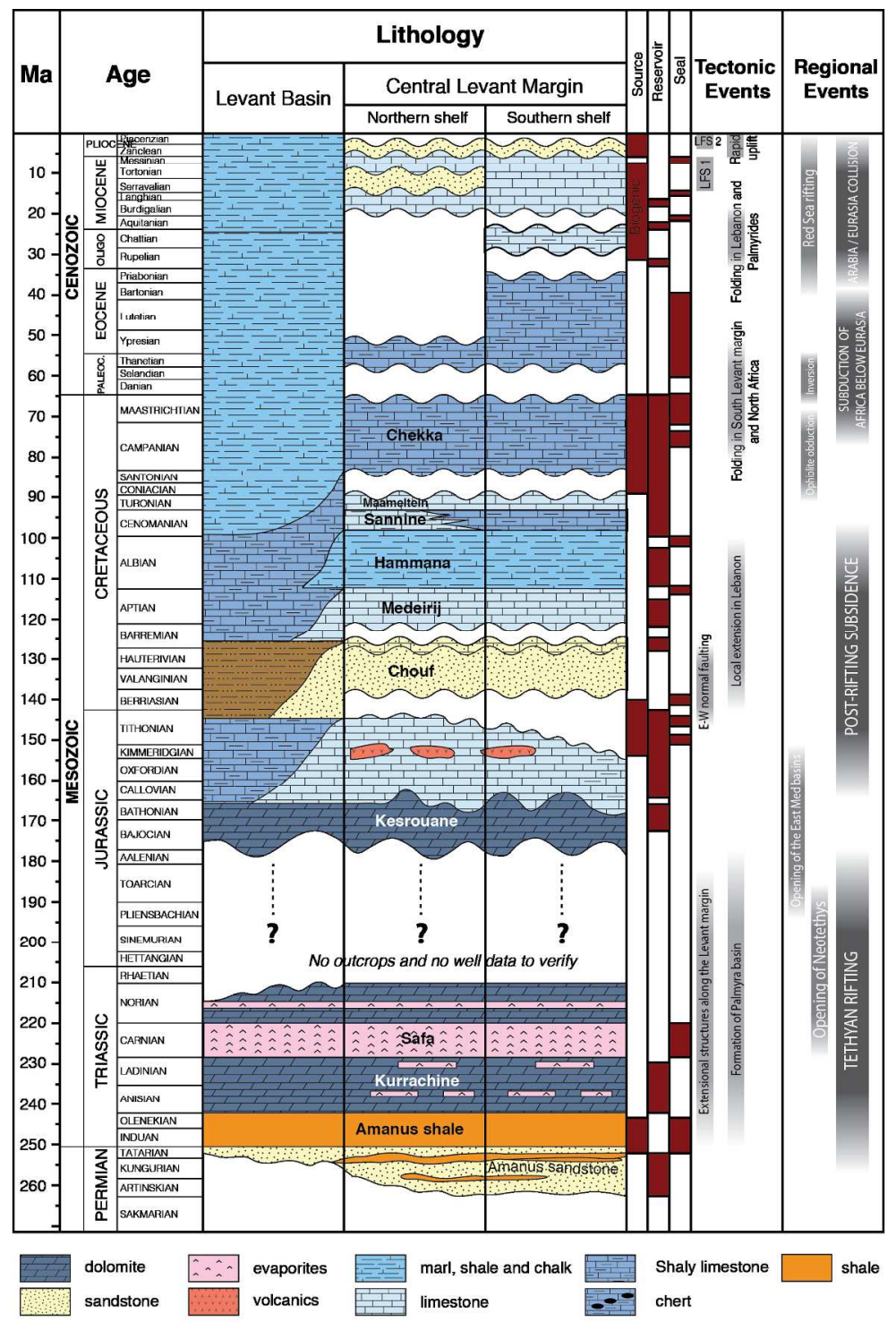

Figure 8

Petroleum potential, stratigraphy and tectonic events for Lebanon and its offshore. 
An example of a NE trending anticline in the deep basin domain offshore Lebanon. The structural style suggests detachment folding on an intra-Eocene horizon. The anticlines were folded in the Late Miocene prior to the Messinian event (Ghalayini et al. 2014). 

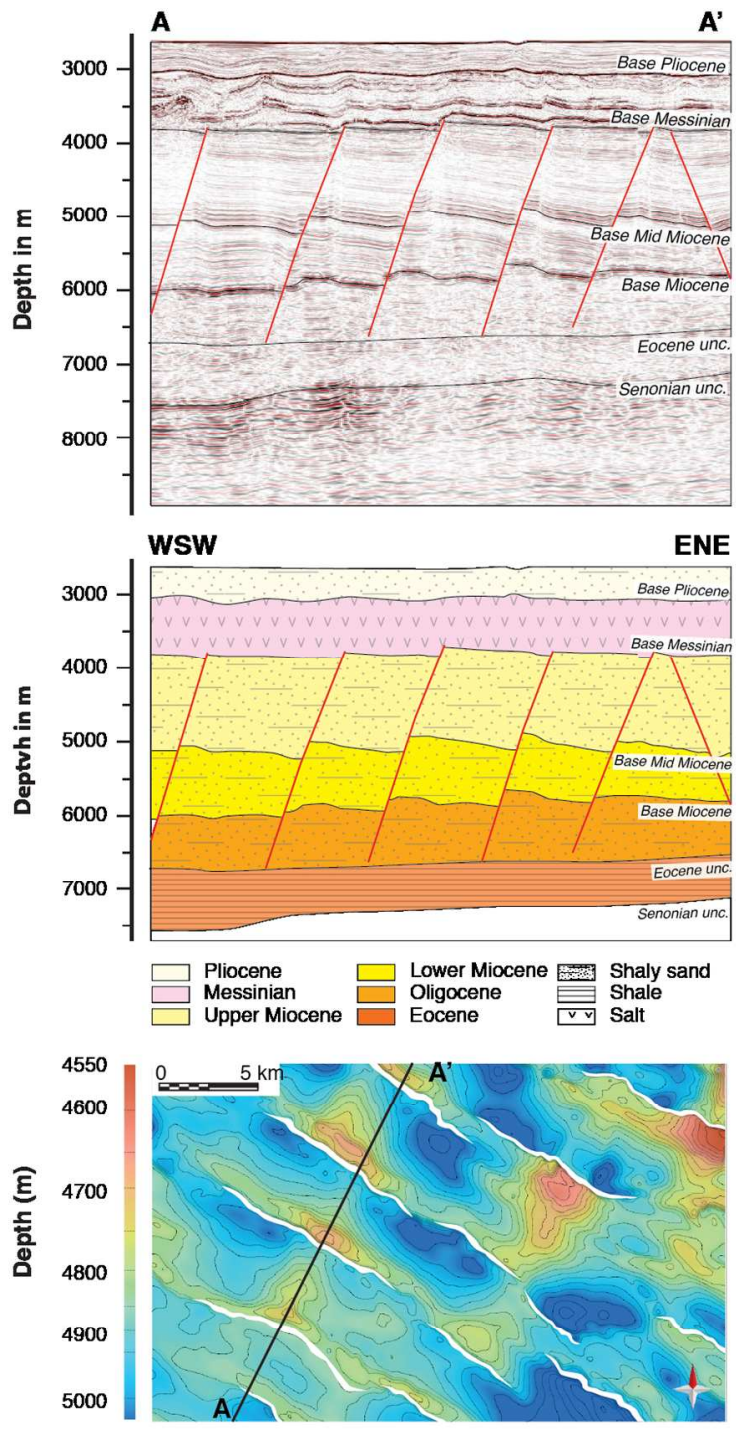

Figure 10

Seismic section showing the titled fault blocks in the deep basin domain. The depth map of the base mid Miocene horizon shows the geometry of the associated traps at present day. 


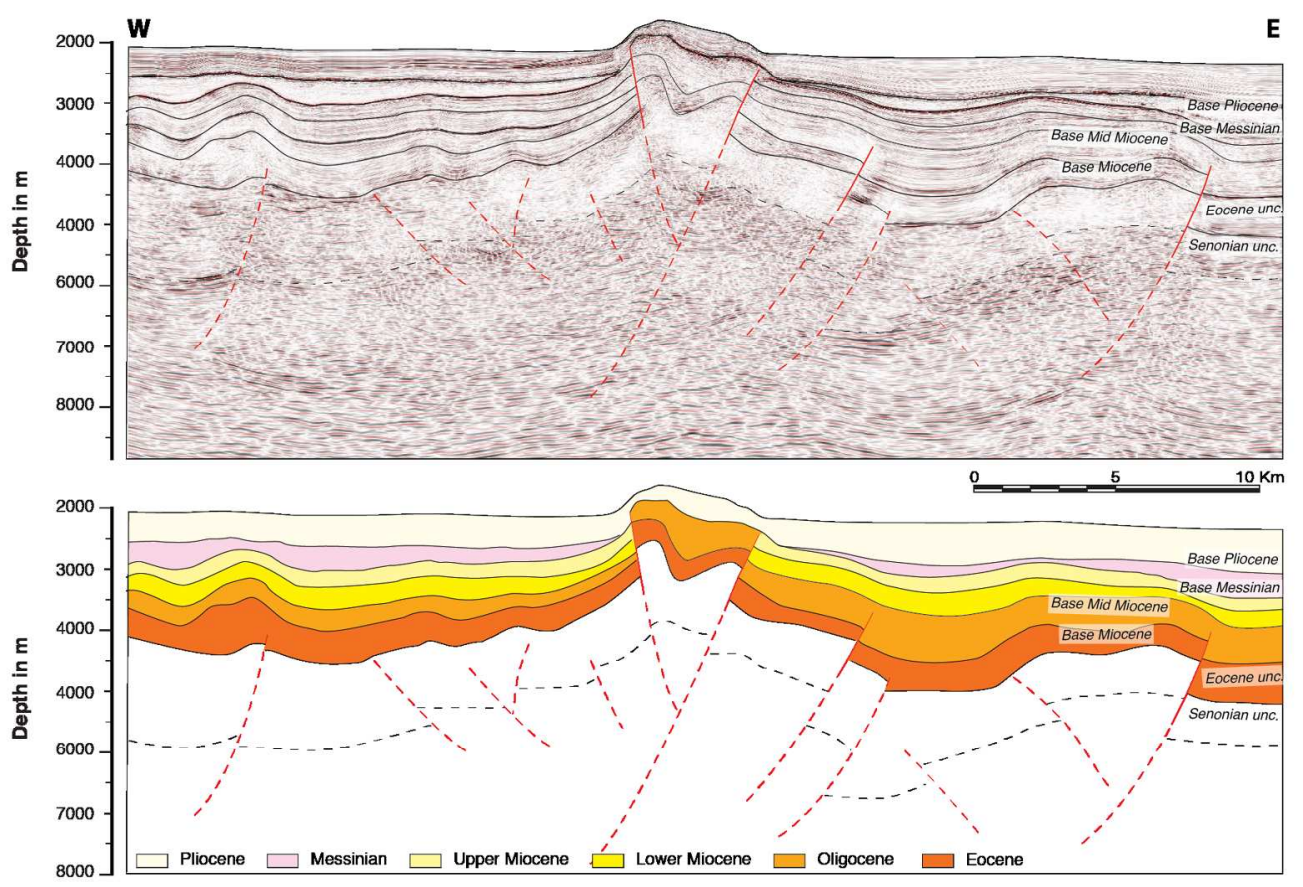

Figure 11

Geo-seismic line showing the Latakia Ridge north of the Levant Basin 

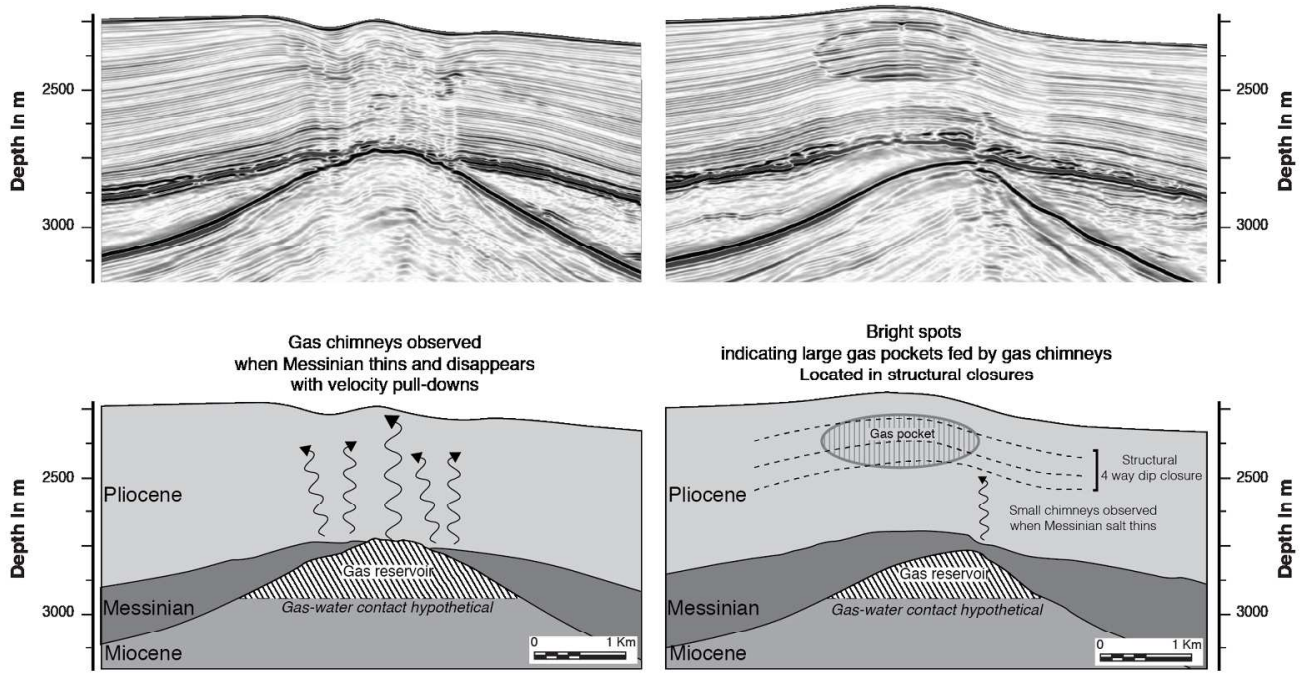

Figure 12

gas chimneys on top of a Miocene anticline observed only when the Messinian seal thins or is absent. The overlying Pliocene exhibits numerous bright spots and DHI's pointing to entrapment of the leaked gas into Pliocene reservoirs in structural closures. 


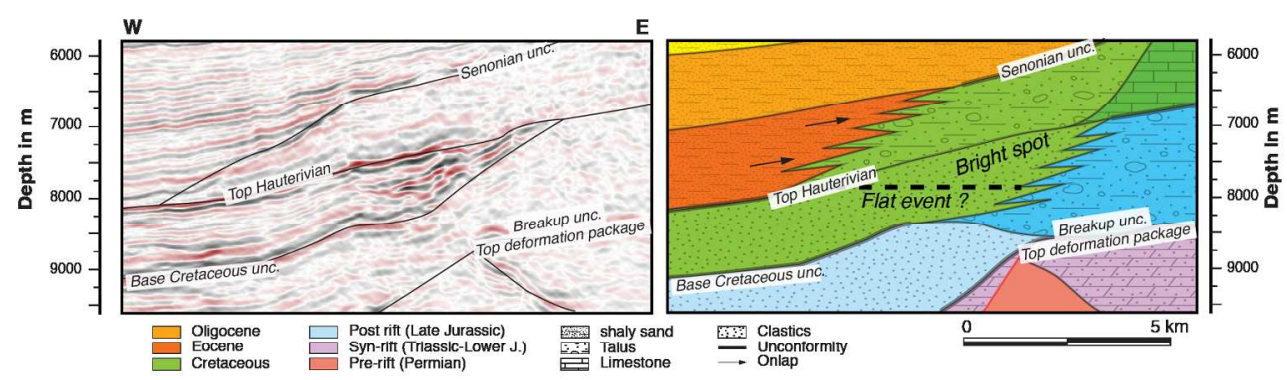

\section{Figure 13}

\section{Geoseismic line showing a bright spot and a potential flat spot in the Lower Cretaceous unit pinching out} along the Levant margin and trapped between Mesozoic carbonates. 

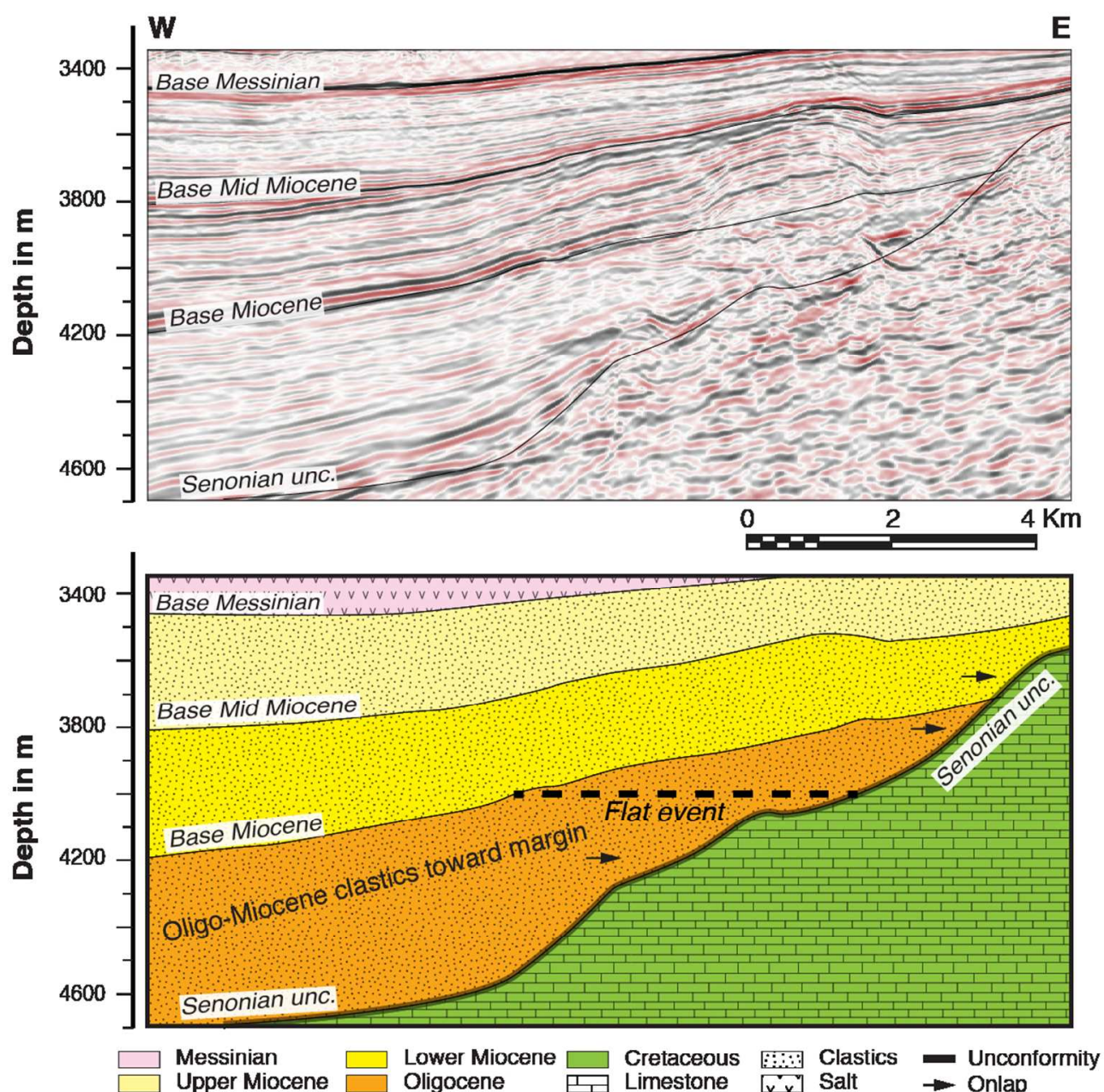

\section{Figure 14}

Geoseismic line showing a potential flat spot in the Oligocene unit observed along the Levant margin. The lateral Oligo-Miocene units are pinching out on the margin forming classical stratigraphic traps. 

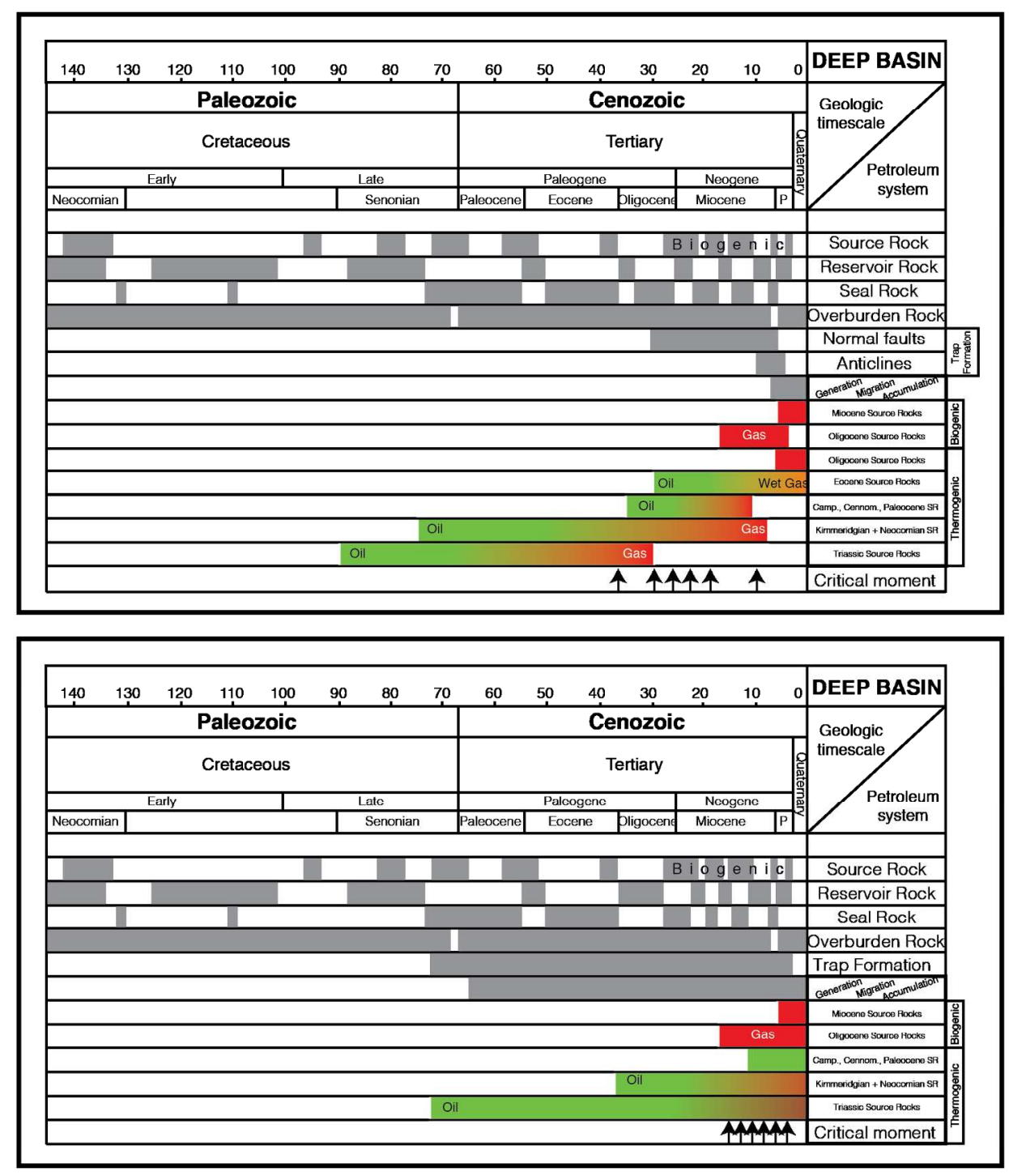

\section{Figure 15}

Petroleum system charts for the deep basin and Latakia Ridge domains. 


\section{Figure 16}

Petroleum system charts for the Levant margin and onshore domains. 